\title{
Fluvial Architecture of the Buntsandstein-facies Redbeds in the Middle to Upper Triassic (Ladinian-Norian) of the Southeastern Edge of the Iberian Meseta (Southern Spain)
}

\author{
Juan Fernández \\ Department of Stratigraphy, University of Granada, Calle Fuentenueva, \\ 18071 Granada, Spain \\ Cristino Dabrio \\ Department of Stratigraphy, University of Salamanca, Plaza de la Merced, \\ 37008 Salamanca, Spain
}

\begin{abstract}
In the southeastern edge of the Iberian Meseta in Southern Spain, fluvial continental Buntsandstein-facies red beds of Middle to Upper Triassic (Ladinian - Norian) age unconformably overlie the folded and eroded Hercynian basement. The Betic Belts consist of an internal metamorphosed part and an external sedimentary zone containing the Triassic deposits, with the latter seam being in turn divided into the Prebetic Zone with continental to shallow marine facies and the Subbetic Zone with pelagic facies. The Buntsandstein-facies red bed series is vertically split into three main facies associations: alluvial fans and pebbly braided rivers (conglomerates and sandstones), low-sinuosity proximal and distal sandy braided rivers (sandstones and mudstones) and coastal evaporitic sabkha (mudstones, marls and gypsum). Alluvial-fan and pebbly braided river sediments occur at the base of the sequence and cover the palaeorelief of the pre-Triassic morphology. The inner fan zone is characterized by debris-flows or mud-flows, the mid fan zone is dominated by sheet floods, and the outer fan zone is governed by stream flood and stream flow passing into pebbly braided rivers in front of the fans. With transition from restricted alluvial fans to an open braidplain, the pebbly rivers soon evolve both vertically and horizontally into sandy stream networks consisting of channels and floodplains. The channel facies comprises sheet-type and ribbon-type sandstone layers. The sheets form complexes up to $15 \mathrm{~m}$ and more thickness due to amalgamation by multilateral coalescence and multivertical stacking of individual genetical units. In the lower part of the series, the number of channels is rather high suggesting a non-hierarchical channel pattern where high- and low-sinuosity rivers coexist. The middle portion reflects a smaller number of very large channels thus indicating an amelioration of the hierarchical pattern. The upper part consists of variegated sabkha plain mudstones and evaporites where channel deposits are almost absent. The floodplain facies is divided into proximal and distal part. The proximal floodplain facies comprises interbedded sandstones and mudstones containing some layers of nodular pedogenic carbonates and originates by overbank sheet-flood, levee overtopping and crevasse-splay sedimentation. The distal floodplain facies is built up of mud with minor layers of silt and fine sand with intercalations of micritic lacustrine limestones and originates in overbank lakes and ponds. Depositional sequences within the sandy braided river series comprise major sequences that are produced by migration of alluvial subenvironments during course of their aggradation, and minor sequences that are related to alternating high- and low-water stages with changing channel abandonment and stream neoformation. The fluvial architecture is highlighted by two types of depositional settings: proximal and distal facies. The proximal facies is characterized by predominantly straight channels without or with only poorly-developed levees and be-
\end{abstract}


ing infilled with sediments under rather high-energy conditions. The distal facies is characterized by low-sinuosity channels surrounded by better developed levees and being infilled under lower energy conditions than the proximal equivalents. With passage from the proximal to the distal facies, the floodplain sediments consist of increasingly more backswamp, levee and crevasse-splay deposits as well as of sediments of small meandering channels operating in the overbank plain between the large main streams. The evaporitic complex at the top of the Triassic originates in an arid coastal intertidal belt and supratidal sabkha seam. Within the sandy braided river complexes, the different magnitudes and effectivities of currents in large channels, small. watercourses and floodplain reaches are underlined by partially divergent, bimodal or even bipolar palaeocurrent directions. Copper mineralizations of mixed syngenetic and epigenetic type in the terrestrial red beds are associated with plant debris in sediments of inactive to abandoned secondary channels and comprise azurite, chrysocolla and malachite. The Triassic palaeogeographical setting represents a large bay between the European and African plates. Fluvio-lacustrine red beds of Buntsandstein facies surrounded the bay and graded laterally into coastal and shallow marine carbonates.

\section{Key words}

Buntsandstein facies, red beds, Middle Triassic, Upper Triassic, Ladinian, Karnian, Norian, Iberian Meseta, Southern Spain; Betic Belts, internal zone, external zone, Prebetic Zone, Subbetic Zone; alluvial-ban, pebbly braided river, palaeorelief; inner fan, mid fan, outer fan, debris-flow, mud-flow, sheet flood, stream flood, stream blow; sandy braided river, channel, sheet, ribbon, floodplain, proximal, levee, crevasse-splay, distal, lake, pond, palaeosol; major sequences, migration of subenvironments, minor sequences, fluctuating flow, avulsion; architecture, proximal model, distal model, levee belt, large major channel, small minor channel, backswamp lake; evaporites, coastal plain, supratidal sabkha, intertidal belt, gypsum, cottage-cheese, chicken-wire; palaeocurrents, divergences, bimodal; economics, copper mineralization, syngenetic, epigenetic, plant debris.

\section{Table of contents}

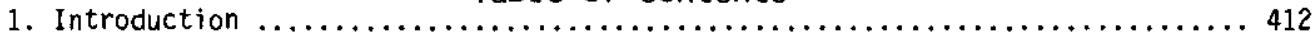

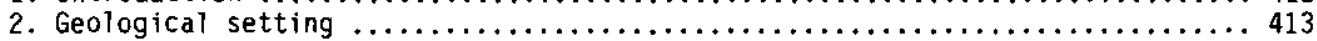

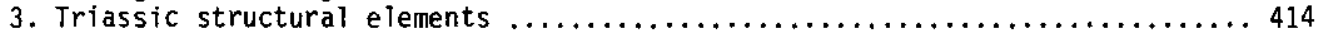

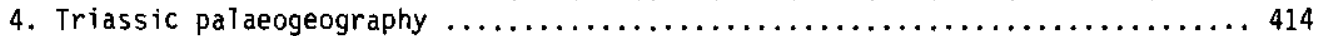

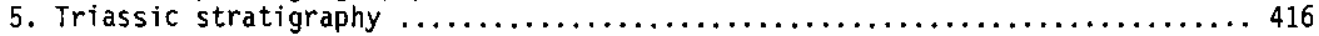

6 . Sedimentary processes and depositional mechanisms ................ 416

6.1 . Al Tuvial fans and conglomeratic braided rivers $\ldots \ldots \ldots \ldots \ldots \ldots \ldots \ldots 416$

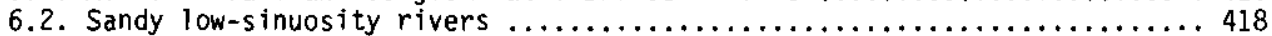

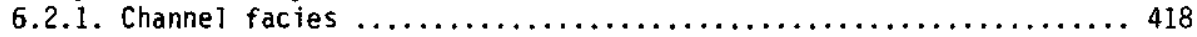

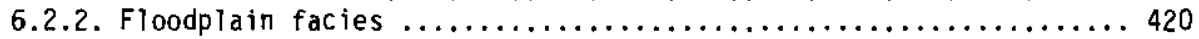

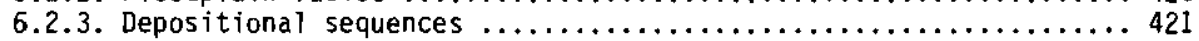

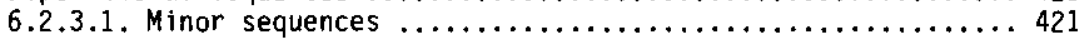

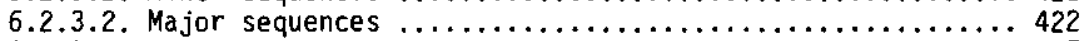

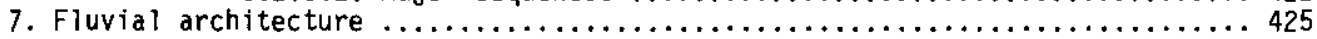

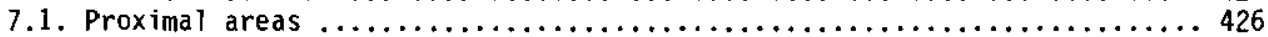

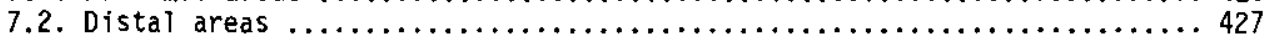

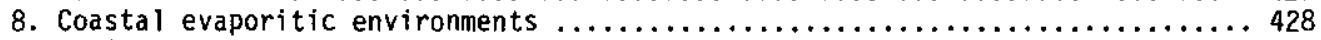

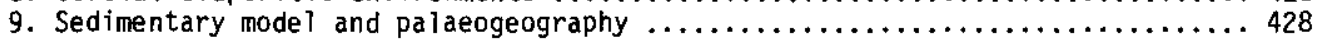

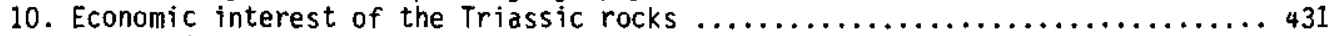

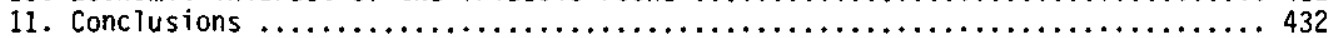

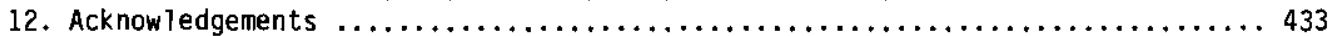

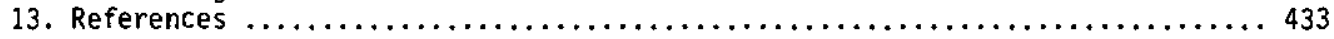

\section{Introduction}

Triassic sediments in Spain crop out in three major belts: the Pyrenees in the north, the Iberian Ranges in the middle and the Iberian Meseta in the south of the 


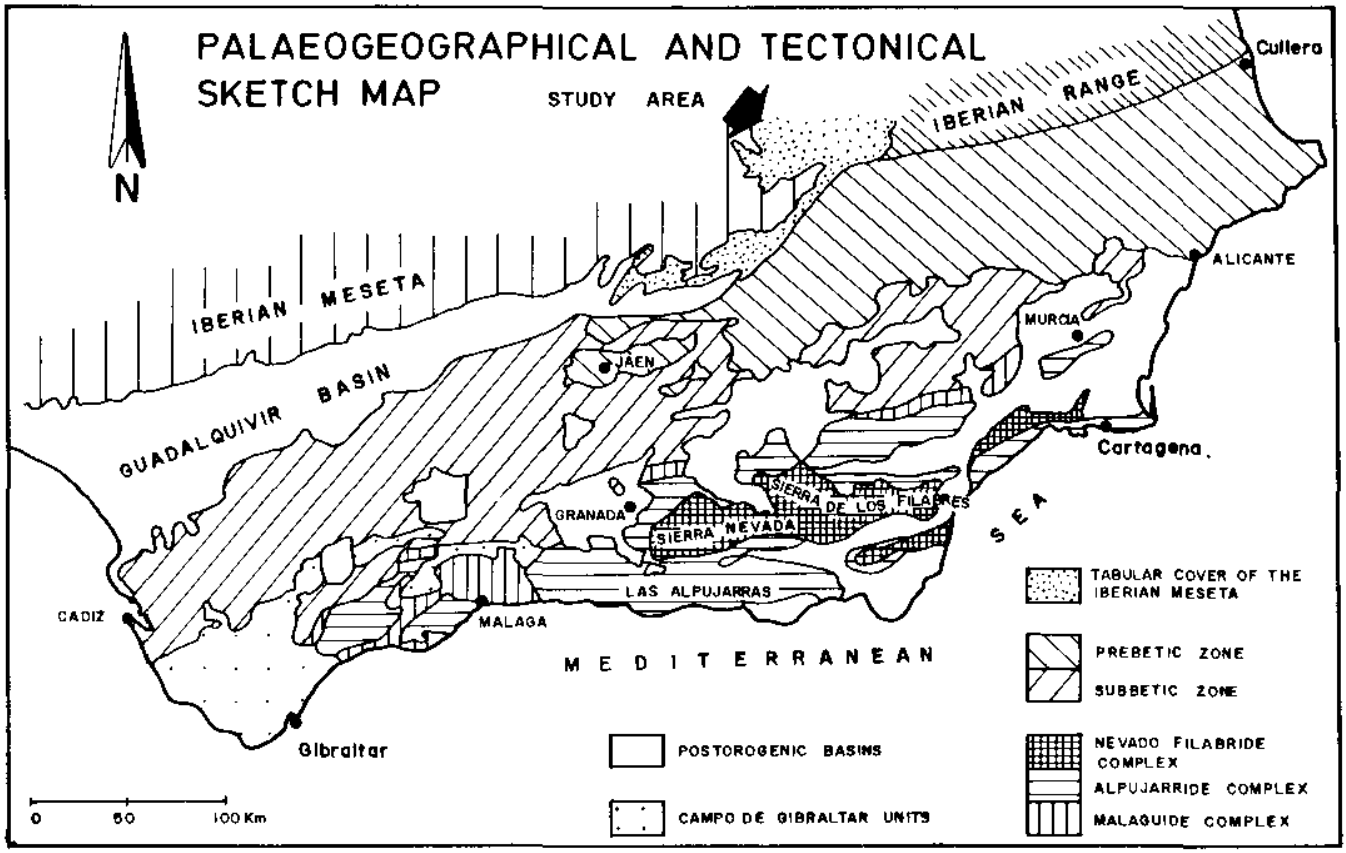

Fig. 1

Palaeogeographical and tectonical sketch map of the South Iberian Peninsula (Southern Spain), simplified after Foucault (1974). For geological sketch map cf. fig. 2.

country. In terms of Buntsandste in facies, the terrestrial red beds of predominantly fluvial origin are quite comparable with the classic germanotype deposits in the Mid-European Triassic Basin.

The continental sediments in the southeastern edge of the Iberian Meseta in Southern Spain have been subjected to detailed sedimentological studies by Fernández (1977, 1984), Dabrio and Fernandez (1980) and Fernandez and Dabrio (1983), with the emphasis having been put on fluvial depositional processes and sedimentary mechanisms. This paper is to summarize the state of knowledge with evaluation of the sequence in terms of fluvial architecture and depositional modelling of mainly sandy braided river systems. Although being of Middle to Upper Triassic age and thus not representing Buntsandstein sediments sensu stricto, the red bed sequence is assessed in the context of its similarity to the Lower Triassic Buntsandstein which is widespread in other parts of Spain and which occurs partially in almost identical facies. For convenience, the Middle to Upper Triassic deposits are named "Buntsandstein-facies red beds " within the descriptions and interpretations as follows.

\section{Geological setting}

The South Iberian Peninsula is built up of two major geological units which comprise the Iberian Meseta and the Betic Belts. The Hercynian massif of the Iberian Meseta is formed by Precambrian and Palaeozoic rocks that were folded during the Carboniferous. Since that period, the Hercynian massif kept being a highland erosional terrain acting as the stable foreland that supplied all the siliciclastic sediments which were subsequently deposited in the Betic realms during the Mesozoic times. 
The Betic Belts comprise the major features of ATpine age in Southern Spain, representing the westernmost units of the Alpine Belts of the Mediterranean area (fig.1). Within the Betic Ranges two main zones can be distinguished.

The internal zones are built up of Palaeozoic (possibly including Precambrian) and Triassic rocks that were metamorphosed during the Alpine orogeny. Younger rocks are only present in some units (Malaguide Complex). During the Triassic, they were placed more to the east, but they approached the Iberian Meseta during the Alpine orogeny due to major movements of the European and African plates.

The external zones consist of Mesozoic and Tertiary rocks which were folded and overthrusted during the Alpine orogeny, with Triassic rocks of Keuper facies being the main slipping layer of the nappes. Two main palaeogeographic realms can be distinguished. The northern domain corresponds to the Prebetic Zone that remained in a position very close to the highland and erosional area of the Iberian Meseta during the deposition of the Mesozoic terrestrial to shallow marine sediments. The Subbetic Zone is the southern domain where pelagic facies and submarine volcanic rocks are well represented since Middle Liassic.

\section{Triassic structural elements}

The Triassic structural elements in the South Iberian Peninsula which can be distinguished across the Betic Cordillera according to facies and structure of the depositional series comprise the southeastern edge of the Iberian Meseta, the external zones of the Betics and the internal zones of the Betics (the differentation into the palaeogeographic realms of the Prebetic Zone and the Subbetic Zone is a younger feature).

In the southeastern edge of the Iberian Meseta, an essentially horizontal Mesozoic unit lies with angular unconformity on top of the Palaeozoic rocks of the Iberian Meseta. This cover consists of Buntsandstein-facies red beds and evaporites. The Muschelkalk-facies is absent.

In the external zones of the Betics, the Mesozoic sequence consists of German-facies sediments including Buntsandstein-facies clastic red beds and evaporites, Muschelkalk-facies carbonate rocks and some (sub)volcanic rocks. The internal tectonic structure ranges from very complex to chaotic which makes the study especially deceptive.

In the internal zones of the Betics, three complexes that represent different palaeogeographic realms can be distinguished. The Nevado-Filabride complex consists of mica-schists, quartzites and marbles that have undergone a complex tectonical and metamorphical evolution. The Alpujarride complex includes Permo-Triassic phyllites, quartzites and carbonates of Alpine facies which display a complicated internal nappe structure. Permo-Triassic sandy and conglomeratic red beds of the German facies are characteristic for the Malaguide complex.

\section{Triassic palaeogeography}

The complex structure of the Betic Cordillera is the result of the interaction of tectonic wovements which can be related to the closing of the Tethys ocean and the rotation of the Iberian Peninsula. To visualize the palaeogeography and structural domains during the Triassic, these movements must be taken into consideration. An attempt to reconstruct the pattern shows several concentric, but irregular facies belts between the European and the African plates.

The Triassic red beds of the Southeastern Iberian Meseta and other materials of German facies of the external zones of the Betics lie on top of the southern margin of the European plate. The Nevado-Filabride complex in assumed to be a metamorphosed 


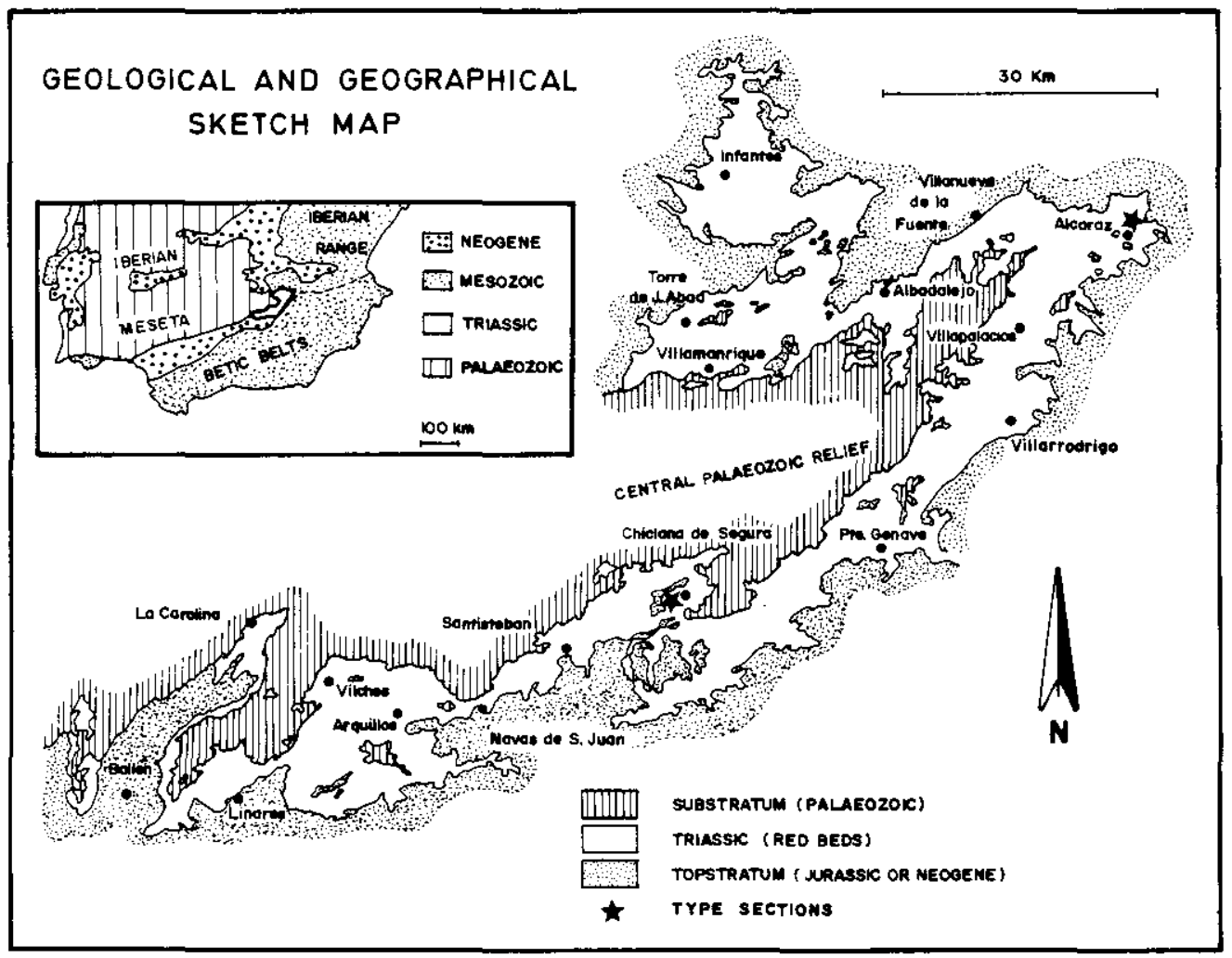

Fig. 2

Geological and geographical sketch map of the South Iberian Peninsula (Southern Spain). For tectonical and palaeogeographical sketch map cf. fig. 1 .

equivalent of these which is placed to the east and which is probably related to an highland erosional mass if that was obliterated during the subsequent Alpine orogeny.

The Alpujarride complex formed in coastal-to-shallow marine environments situated at an unknown distance to the east. The so-called Betic Dorsal and U1trainternal Subbetic domains most probably represent deposits of mitieus placed in a transitional zone between the characteristic German and Alpine (Alpujarride) realms.

The Malaguide complex was the northern siliciclastic belt along the margin of the African Plate ( $c f$. Bourgois 1980). The palaeogeographical model consists of a large marine bay surrounded by German-facies terrestrial braidplains and playas which are developed at the edges of the European and African plates, grading laterally into the Alpine-facies coastal and shallow marine environments (Alpujarride complex) which extended to the east where the Triassic Tethys lay.

After deposition of the Buntsandstein-facies, several marine transgressions took place and coastal-to-shallow marine sediments of Muschelkalk-facies spread over the fluvio-lacustrine coastal environments extending towards the continent during Upper Triassic times. The facies patterns and sea-level changes are the major controls for the palaeogeographical evolution. The active and complex subsequent geological history introduced further changes that obliterated many primary-depositional features. 


\section{Triassic stratigraphy}

The Betic Triassic sediments lie unconformabiy on top of the older Hercynian rocks, both along the southern edge of the Iberian Meseta and in the Internal Zones. Along the southeastern border of the Meseta, a belt of horizontal red beds crops out, which behaved as a rigid unit during the Alpine orogeny, forming an undeformed cover of the Palaeozoic socle. For this reason this unit has been often referred to as "the tabular cover of the Iberian Meseta" in contrast with the deformed Mesozoic and Tertiary units of the Betic Belts (López Garrido 1971, Fernández 1977).

The Hercynian rocks of the basement belong to the "Central-Iberic Zone" of the Spanish Meseta. An Ordovician to Early Carboniferous siliciclastic section has been described from this area (Tamain 1970), but plutonic granites and related magmatic rocks are also present.

The northwestern liuit of the described red beds is of erosional type. Towards the north and northeast, they are covered by horizontal Jurassic dolomites, whereas towards the southeast they grade into the folded Betic Belts. To the south they are unconformably overlain by the Meogene Units of the Guadalquivir Basin (cf. figs. 1 and 2).

According to palynological investigations (Bessems 1981) of the Tabular Cover (= Chiclana de Segura Formation, López Garrido 1971), the age ranges from Ladinian at the base to Early Norian at the top, with thus sedimentation along the southern margin of the Iberian Meseta not having started before Ladinian times (thus the Buntsandstein facies ascends into higher stratigraphic levels). The Lower and early Middle Triassic periods which are represented by Buntsandstein-facies and Muschelkalk-facies deposits in many other areas are therefore only represented in the major diastea, and the Buntsandstein-facies red beds cropping out in the southeastern edge of the Iberian Meseta are indeed of Middle to Upper Triassic age.

\section{Sedimentary processes and depositional mechanisms}

The Buntsandstein-facies red beds in the southeastern edge of the Iberian Meseta consist of three main facies associations:

1. A conglomerate and sandstone facies association which (when present) occurs as a basal member of the section and was generated by alluvial fans and pebbly braided rivers.

2. A facies association consisting of mudstones with interbedded sandstone layers corresponding to low-sinuosity sandy rivers in proximal or distal braided systems.

3. A mudstone, marl and gypsu facies association at the top of the section, representing coastal evaporitic environments.

These sediments are mainiy exposed in two extensfve outcrops near chiclana de Segura (cf. fig. 3) and Alcaraz (cf. fig. 4) which have been evaluated for the description and interpretation as follows (additional data derive from Fernández 1977 and Dabrio and Fernändez 1980).

\subsection{Alluvial fans and conglomeratic braided rivers}

Poorly-developed conglomerate deposits which originated in alluvial fans and conglomeratic braided rivers occur at some places near the exhuned palaeoreliefs (particulariy in Villamanrique, cf. fig. 5). The deposits are attributed to the three zones of alluvial fans (McGowen and Groat 1971).

The inner fan facies (proximal facies) consists of quartzite pebbies and cobbles (including some boulders) in a dominantly fine-grained (muddy) matrix. The resulting unstratified and structureless conglomerates are interpreted as debris-fion and mod-flow deposits (cf. Plate I/9). Considering that they are in contact with the 


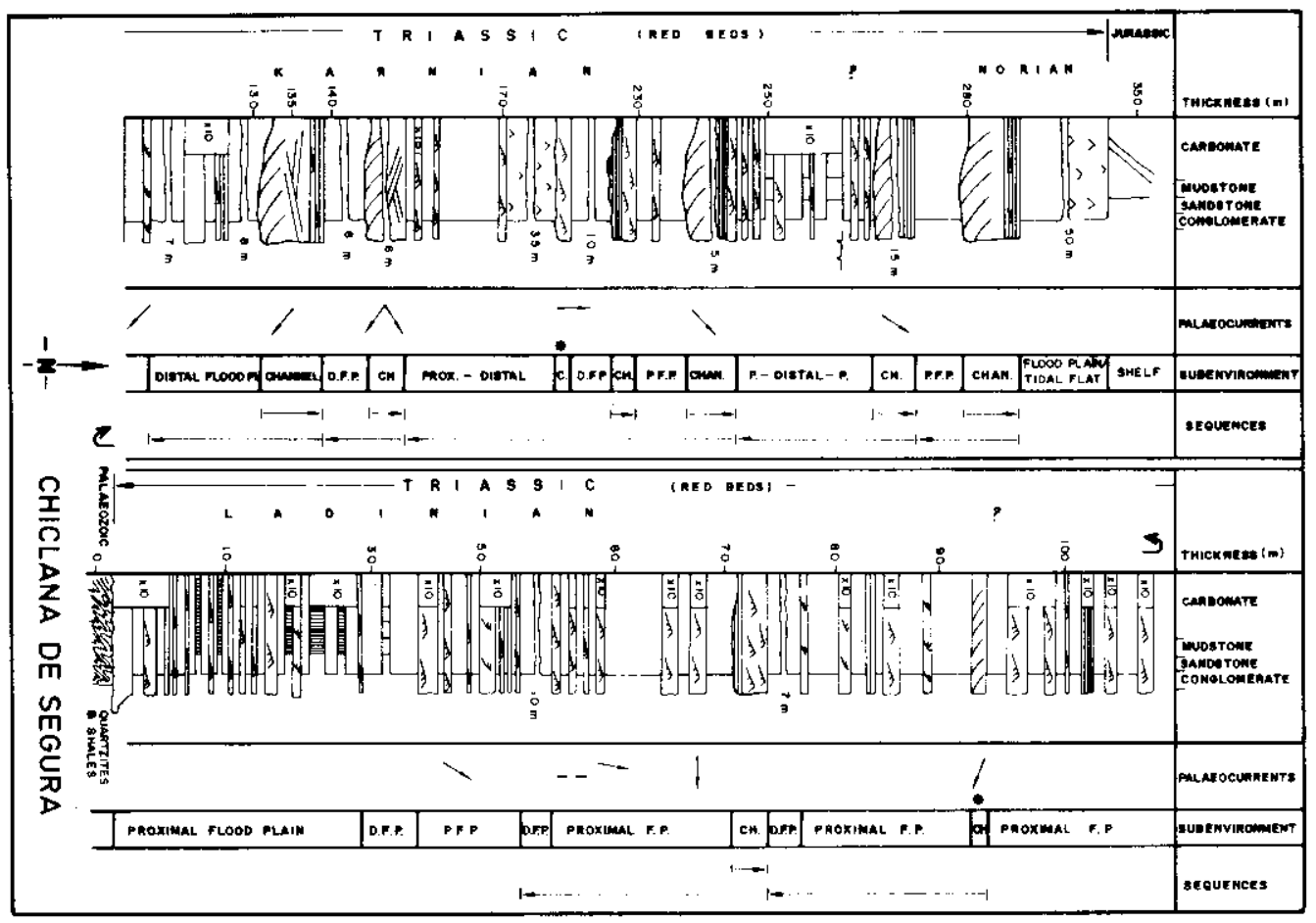

Fig. 3

Stratigraphic section of the Triassic red beds in the neighbourhood of Chiclana de Segura. Various subenvironments are distinguishable together with distinct sequences related to the predominating conditions in these subenvironments or with their movement in space and time. For legend cf. fig. 4.

palaeorelief and assessing the sedimentary processes involved, they are attributed to the inner zones of a small-size alluvial fan.

The mid fan facies (medial facies) shows characteristic fining-upwards sequences including three members. The lower one is the lateral equivalent of the inner fan conglomerate facies and consists of poorly-sorted clast-supported quartzite gravels with only a little matrix made of sand and lutite. The internal structure is very poor, but some crude horizontal-bedding is visible. The lower boundary of the units is sharp. Low-viscosity flows are assumed which probably resulted in construction of longitudinal bar deposits within alluvial channels (Smith 1974). On top of this, a $25 \mathrm{~cm}$ thick layer of even-laminated sand displaying sharp lower boundary is interpreted as sheet flood deposits (Bull 1972) or low-stage stream flow sediments. Subsequent pedogenic cementation by calcium carbonate and iron oxides suggest an arid to semi-arid climate. The top of the sequence consists of a mud drape formed by waning-flow settling of fines.

The outer fan facies (distal facies) or congloweratic braided river deposits also display a fining-upwards sequence which reflects decreasing flow conditions. The 10wer member consists of conglomerates with coarse sandy matrix. Locally, imbrication and horizontal-lamination or low-angle cross-bedding can be seen. This facies grades upwards into cross-bedded coarse sand and pebbles and higher up into clay (cf. Plates I/2 and II/I). The coarse member can be interpreted as longitudinal bars in active channels, whereas the sand-clay member would represent deposits related to the decrease of flow in the channel or sediments of interchannel overbank areas. Deposition is dominated by strean-flood and stream-flow processes. 


\section{Plate I}

1 : Panoramic overview of the Triassic red beds in Alcaraz. $P=$ Palaeozoic basement, $C=$ channel facies, $p f p=$ proximal floodplain facies, $d f p=$ distal floodplain facies, $E$ = evaporitic unit, $J$ = Jurassic carbonates.

2 : Conglomeratic braided river deposits (outer fan). The lower part of the fining-upwards sequence consists of clast-supported conglomerates with crude horizontal-stratification, whereas the upper part is built up of cross-bedded coarse sands passing into parallel-laminated medium sand and mud. Enlargement from Plate II/l. Length of hammer $28 \mathrm{~cm}$.

3 : Pebbly braided river deposits. The sequence consists (in ascending order) of conglomerate, pebbly coarse sand and parallel-laminated to cross-stratified medium sand. Enlargement from Plate II/l.

4 : Interference ripples at the top of a sandstone layer in the upper part of a channel-fill sequence. The overprinting of the earlier ripple trains originated after upstream avulsion. Length of pencil $18 \mathrm{~cm}$.

5 : Laminated carbonates were deposited in ephemeral lakes in the floodplain. Diameter of fig. abt. $1 \mathrm{~m}$.

6 : Evaporitic gypsum facies showing (in ascending order) banded gypsum (algal mat), chicken-wire gypsum and nodular gypsum in grey to green mudstone. The gypsum sediments originated in supratidal to intertidal reaches of a sabkha in an arid coastal plain.

7 : In sandstone beds of the proximal floodplain facies, the internal structures successively comprising cross-bedding, horizontal-stratification and ripple cross-lamination record the progressively decreasing current energy both towards the top with advancing accretion and towards more distal parts of the floodplain away from the channels. Diameter of fig. abt. $70 \mathrm{~cm}$.

8 : The distal floodplain facies mainly consists of red mudstones with intercalated calcrete palaeosols (P) and fine overbank sheet sandstones (d) and are overlain by thick channel sandstones $(\mathrm{CH})$. Note the erosional lower boundary of the channel facies and the absence of proximal floodplain deposits. Diameter of fig. abt. $5 \mathrm{~m}$.

9 : Matrix-supported conglomerates of debris-flow origin in the inner fan reach. Diameter of fig. abt. $80 \mathrm{~cm}$.

The restricted alluvial-fan facies gives distally way to pebbly braided rivers of an open braidplain. The most representative sequences are built up of conglomerates at the bottom, passing upwards via coarse sand with cross-bedding to medium and fine sand with horizontal-stratification and cross-lamination (cf. Plates I/3 and II/1).

\subsection{Sandy low-sinuosity rivers}

Successions laid down in these sedimentary environments consist of interbedded mudstone and sandstone along with a few carbonate layers (cf. Plate I/9). From the analysis of 7 ithological associations, lateral and vertical sequences of facies, morphology of sedimentary bodies and palaeocurrent indicators, a fluvial environment was deduced (Fernández 1977). Several sedimentary facies related to the fluvial environment have been described and interpreted (Dabrio and Fernández 1980) comprising channel facies and floodplain facies.

\subsubsection{Channel facies}

The channel facies consists of thick sandstone layers (mean thickness about 15 $m$ ). The prevalent internal structure is large-scale cross-bedding, plane-stratification and cross-lamination. Scoured surfaces bounding the individual sheets and cosets are common. In some cases, the diastems represent the changing morphology of the bottom of the channel during high-water stages and are related to high-energy sedimentary structures. In other cases, the erosionat boundaries are associated to deposition of fines and pedogenic processes at the top of sequences of upwards-decreasing energy as witnessed by sedimentary structures and sometimes also grain size. The existence of scouring records the alternance of high-water stages with 

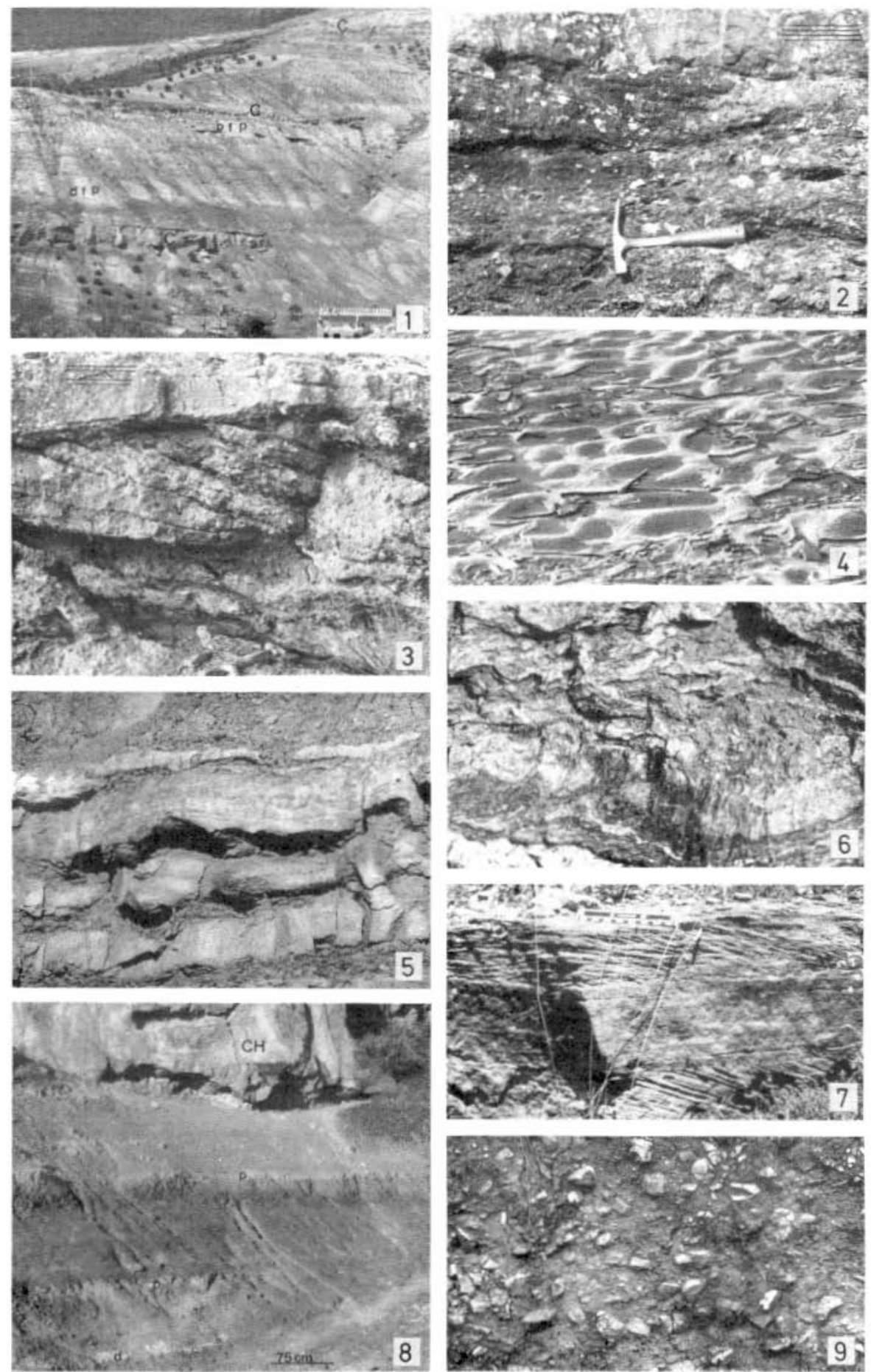

Plate I 
erosion and incision and low-water stages with deposition. Minor fluctuations in discharge are registered by internal reactivation surfaces on large-scale bedforms (Collinson 1970, 1978).

The morphology of the resulting sedimentary bodies is mostly tabular (sheet sandstone bodies; Friend, Slater and Williams 1979), because they are laid down in continuously aigrating channels with very high width-depth ratios. The sandstone sheets also originate by multilateral coalescence and multivertical stacking of individual genetical units. In the lower part of the sections, the number of channels is rather high suggesting a non-hierarchical channel pattern where high- and low-sinuosity rivers (Moody-Stuart 1966) can coexist. High-sinuosity rivers are represented by ribbon sandstone bodies (Friend, Slater and Williams 1979; Friend 1983, Stear 1983) which are smaller in scale than sheet sandstone bodies. The middle third of the sections shows a smaller number of very large channels thus indicating an anelioration of the hierarchical pattern. The upper third is made of variegated mudstones and evaporites where channel facies sediments are almost absent.

According to all these features, the sandstone layers are interpreted as deposits of low-sinuosity seasonal sandy rivers.

\subsubsection{Floodplain facies}

Within the floodplain facies, two types reflecting distinct sedimentary processes are distinguished on the base of lithology, thickness of strata and sedimentary structures; proximal and distal floodplain facies (cf. Dabrio and Fernández 1980).

The proximal floodplain facies (Plate II/4) consists of interbedded mudstones and sandstones with small-scale sedimentary structures and some layers of nodular pedogenic carbonate. The sandstone beds were deposited during waning periods of floods due to the sudden deceleration of the current velocity. Decreasing energy both vertically (fining-upwards sequence) and horizontally away from the channel (cross-bedding and plane-stratification passing into cross-lamination and wavy bedding) is reflected in the sequence (Plate I/7). The terminal stage comprising emergence is sometimes punctuated by desiccation cracks at the top of the sandstones (Plate II/8). The sandstone beds can be interpreted as overbank sheet flood deposits when they are tabular in morphology and very extensive, and as crevasse-splay deposits when they are pinching out quickly (cf. Allen 1964, Leeder 1974).

The overbank sheet-flood and crevasse-splay sandstone layers are interbedded with mudstones which were deposited from suspension-load after recession of flood waters. Sand/nud rates and thicknesses of the sandstone layers decrease away from the channels with declining environwental energy in standing lakes, ponds and puddles.

Development of vegetation which was favoured by the proximity to the channels could take place on palaeosols which originated in seai-arid climate. Important pedogenic processes such as growth of carbonate nodules in the ground were triggered by the roots of the flora. The carbonate concretions occur in the $B$ horizons of more or less well-developed palaeosols and contain iron and manganese oxides. Sometimes, al so mature caliches are present which are very similar to those developed in modern semi-arid regions (cf. Allen and Leeder 1975).

The distal floodplain facies is built up of aud with minor layers of silt and fine sand, transported as suspension-load, as well as of $10-25 \mathrm{~cm}$ thick layers of laminated micritic limestones (P]ate I/5) with bird-eye textures and localiy containing ostracods, algal mats and desiccation cracks. According to Friend and Moody-Stuart (1970), these limestones were precipitated in epheeral floodplain lakes where occasionaliy also gypsu could form. 


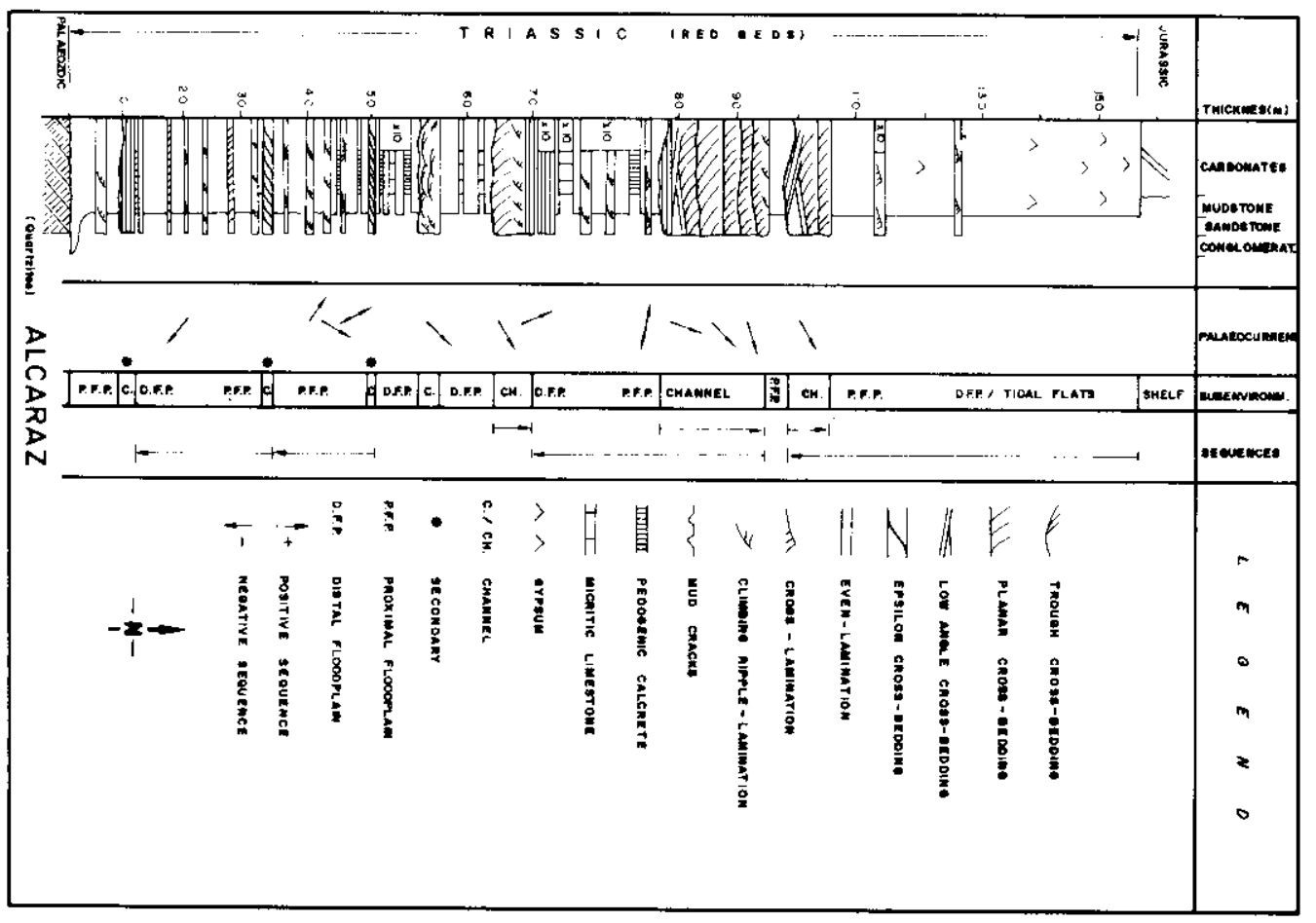

Fig. 4

Stratigraphic section of the Triassic red beds in the neighbourhood of Alcaraz. Various subenvironments are distinguishable together with distinct sequences related to the predominating conditions in these subenvironments or with their movement in space and time. Legend to figs. 3 and 4.

\subsubsection{Depositional sequences}

Concerning organization of the depositional record, distinction can be made between minor sequences generated by sedimentary processes acting within the alluvial subenvironments, and major sequences related to migration of submilieus across others.

\subsubsection{Minor sequences}

Minor sequences are related to alternating high- and low-water stages and changing channel abandonment and stream neoformation. Three types are distinguished (cf. fig. 6): channel sequences, proximal floodplain sequences and distal floodplain sequences.

Channel sequences are fining-upwards sections (upwards-decreasing energy; $c f$. PTate $I I / 9)$. The erosional base of the channel and the dominance of cross-bedded sandstones are good indicators of rather high-energy, active transport and powerful deposition. The transition from large-scale cross-bedding to low-energy even-lamination is related to partial abandonment of the channel when avulsion occurs upstream and most of the flow is diverted to a new channel. The generalized fining-upwards sequences found in channel deposits include smaller fining-upwards sections separated by scouring surfaces (microcycles, cf. Allen 1965), all of them recording the complex depositional history of the channel and the seasonal fluctuations of the hydraulic systems. 


\section{Plate II}

1 : Lateral evolution from conglomeratic braided river facies (CBR) to pebbly braided river facies (PBR). For enlargements cf. Plates $I / 2$ and $I / 3$.

2 : Sabkha deposits showing mudstones with gypsum nodules which become more abundant towards the top where they finally coalesce to form a continuous layer with cottage-cheese fabric.

3: Calcrete palaeosol with upwards increasing content of carbonate nodules. Scale in the upper left $=5 \mathrm{~cm}$. Enlargement from Plate $\mathrm{I} / 8$.

4 : Proximal floodplain facies (below) consisting of alternating fine sand and mud, overlain by channel facies (above). Both units form a thickening- and coarsening-upwards sequence which is related to the lateral migration of the channel. Diameter of fig. abt. $4.5 \mathrm{~m}$.

5 : Channel facies consisting of horizontal-lamination (upper-flow regime) and large-scale cross-bedding (higher reach of lower-flow regime) which record the elevated energetic conditions existing during the initial stages of infilling of the stream course. Enlargement from Plate II/9. Diameter of fig. abt. $70 \mathrm{~cm}$.

6 : Within cosets of cross-stratified channel sandstones, the decreasing set thickness towards the top reflects declining energy during accretion of the stream. Diameter of fig. abt. $3.5 \mathrm{~m}$.

7 : Ripple cross-lamination (section transverse to flow direction) within proximal. floodplain deposits. Enlargement from Plate $1 / 7$.

8 : The top of a sandstone bed in the proximal floodplain facies is intersected by mud cracks and perforated by burrows. Length of hammer $28 \mathrm{~cm}$.

9 : Fining-upwards channel sequences reflecting decreasing energy during course of aggradation of the stream. The upper-flow plane beds in the lower part of the section pass upwards into lower-flow regime cross-strata and parallel-laminae in the upper part. For enlargement $\mathrm{cf}$. Plate II/5. Diameter of fig. abt. $7 \mathrm{~m}$.

10 : Even and wavy horizontal-laminated fine sandstone which is cut by minor scour surfaces was deposited in low-energy slowly-flowing water after avulsion of the stream. Channel facies of proximal areas. Scale in the lower right $=5 \mathrm{~cm}$.

11 : Horizontal-lamination of upper-flow regime type in the channel facies sediments records the high energy level existing during the early stages of infilling of the stream in proximal areas. Scour surfaces separate phases of infilling of the watercourse.

In the proximal floodplain, fining-upwards sequences occur within the sandstone layers. Considering the thickness of such beds, however, thickening-upwards sequences are common (Plate II/4) which are related to the increasing extent of sheet-type overbanking when the channel is filled with sediments ( $c f$. fig. 7 , upper part).

In the distal floodplain, no definite sequences are found. Monotonous successions of red mudstone with random intercalations of laminated carbonates, thin layers of fine sand to silt grain size, and pedogenic horizons are the most likely to the found.

\subsubsection{Major sequences}

Major sequences are produced by the interrelationship and migration of subenviroments. When a channel is established on a place, the main process is erosion. The newly founded channel which is scoured into the substrate is eapty, and, beginning from this stage, vertical accretion (with different rates of sedimentation according to the type and degree of shifting of subenvironients) occurs. The upwards diminishing grain size in the channe] sequences reflects decelerating transport potential with continuing aggradation of the stream and shallowing water depth. As the channel is progressively infilled with sand, the probability of overbanking during high-water stages is progressively ameliorating, and the levee-type rias of sandy overbank deposits along both margins of the channel become more and more we 11-developed (fig. 7, upper part). In this way, thickening-upwards sequences are generated in the proximal floodplain. 

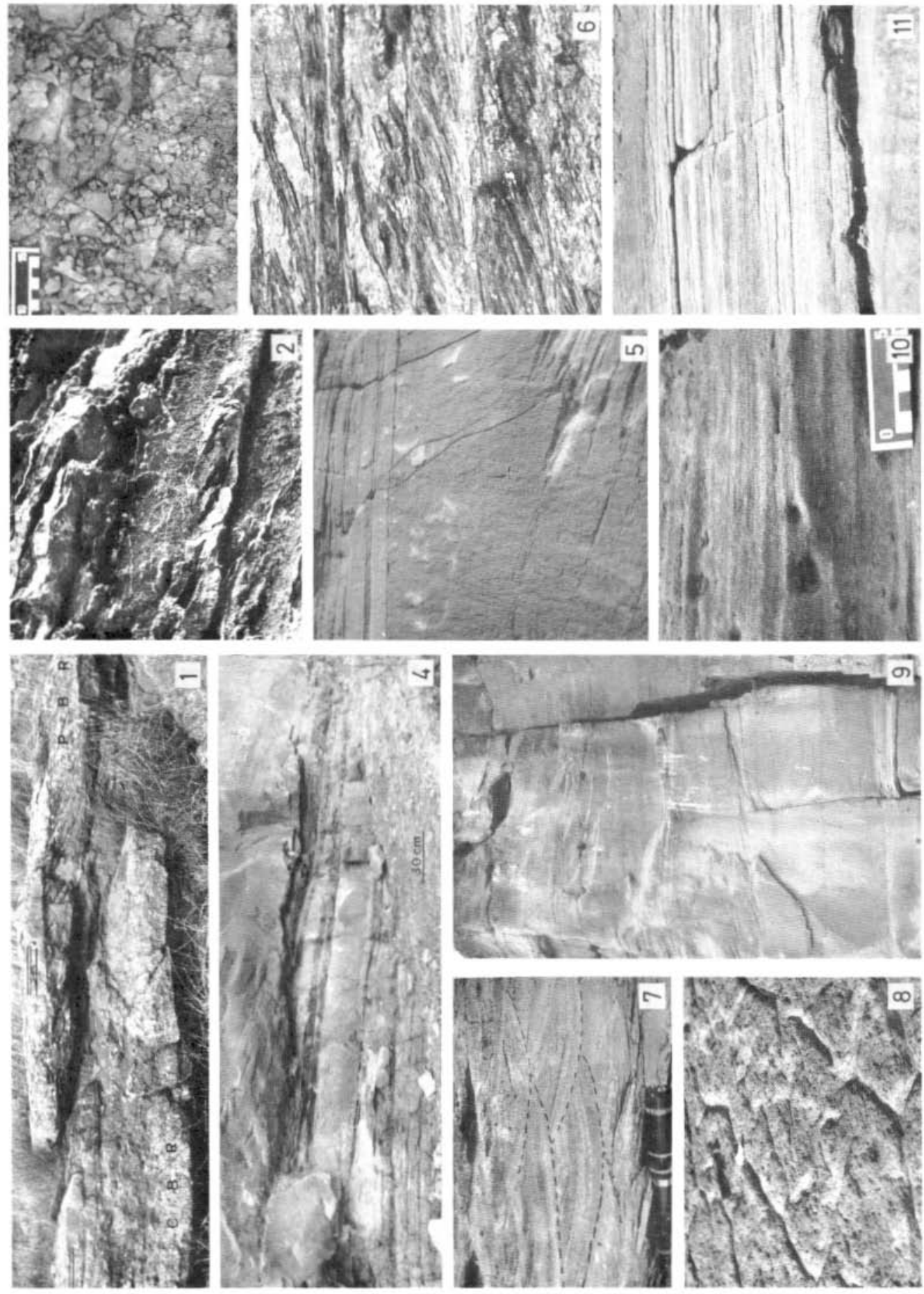

Plate II 


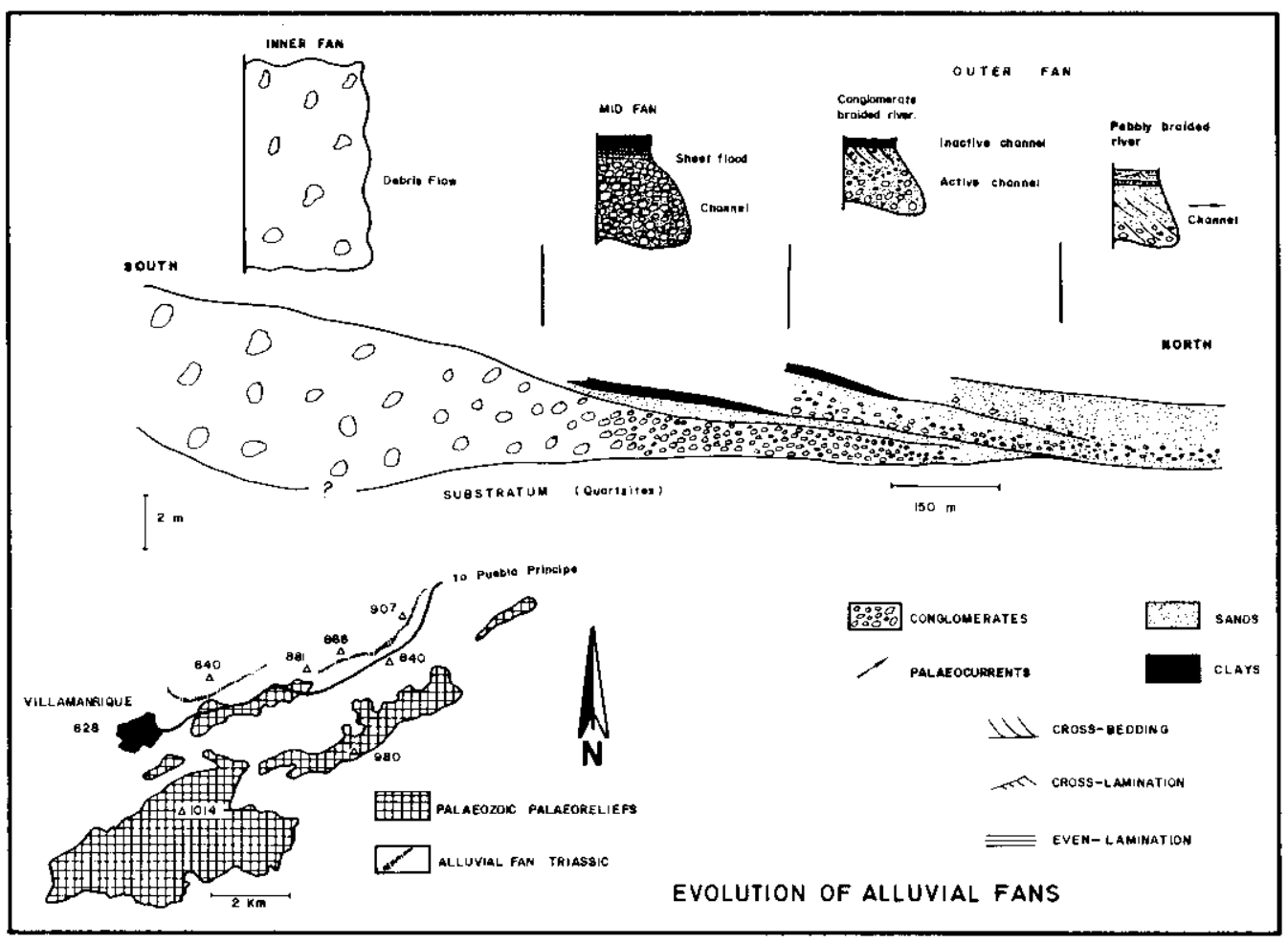

Fig. 5

Alluvial-fan deposits northeast of Villamanrique, showing an evolutionary scheme of proximal to distal facies, together with the facies and sequences which characterize the different parts of the fan (modified after Fernández 1984).

Fig. 6

Conceptual models of characteristic sequences generated by sedimentary processes acting in fluvial subenvironments (modified after Dabrio and Fernández 1980).

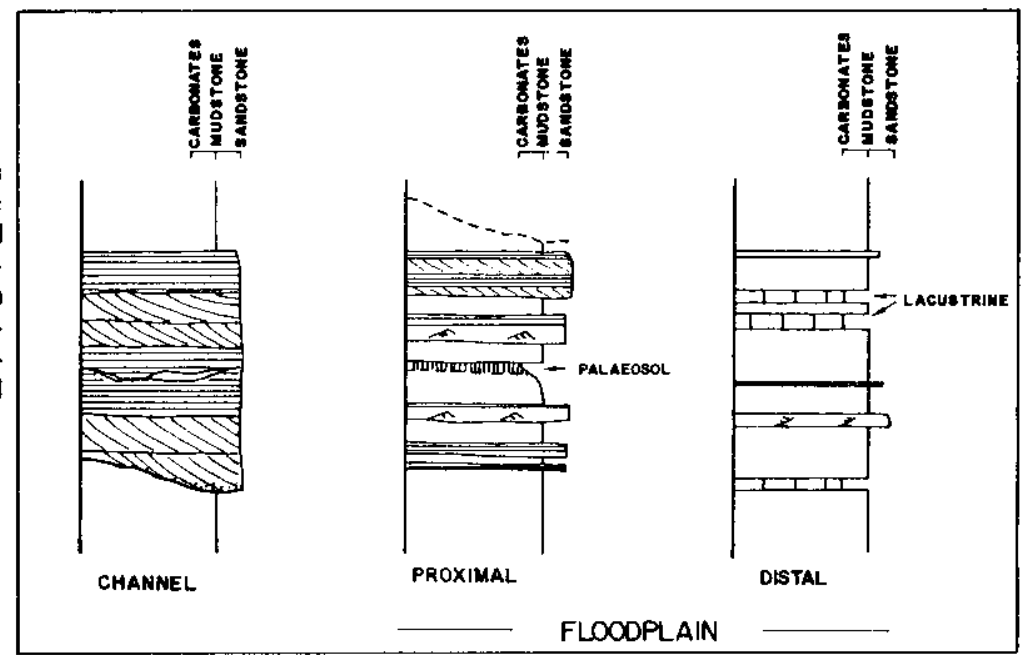




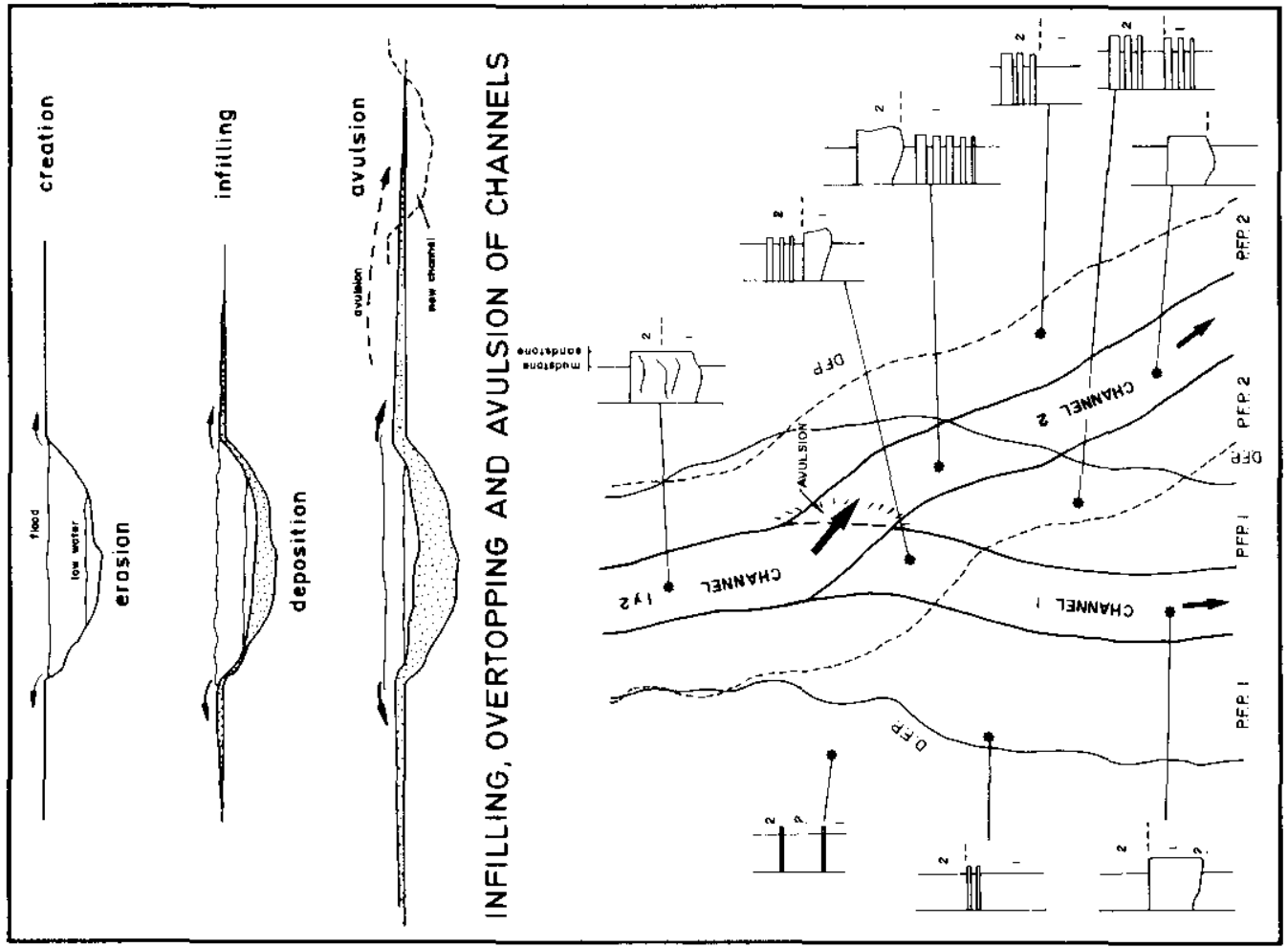

Fig. 7

Vertical and horizontal changes during course of aggradation of fluvial streams (schematically, no scale). Upper part: several stages of the depositional history of the channel. Lower part: ideal sequences, generated when a channel migrates by avulsion from 1 to 2 . In the sections, the sediments related to channels 1 and 2 are indicated by 1 and 2 , respectively. P.F.P. = proximal floodplain, D.F.P. = distal floodplain (modified after Dabrio and Fernández 1980).

Finally, the channel becomes unstable due to the high level which is reached by the sandy infilling, and subsequently, the stream moves to a new place by avulsion. Downstream from the avulsion site, a dramatic decrease of energy is recorded by a change from high-energy cross-bedded sands to low-energy plane-stratified and cross-laminated sands. The new channel is subjected to a similar depositional evolution and, with its progressive infilling, new levee-type rias of overbank deposits overlying older sediments of the distal floodplain are formed. The repeated migration of subenvironments thus results in various types of sequences according to the spatial location of the sections with respect to the channel and the floodplain patterns and the texporal shifting of the submilieus (cf. fig. 7, lower part).

\section{Fluvial architecture}

Following description and interpretation of sedimentary processes and depositional wechanisas with evaluation of the fabric of fluvial megasequences and microsequences, the organization of the alluvial facies throughout the whole type sections is assessed in terms of reconstruction of the architecture of the fluvial system in time and space. According to the characteristic features and distribution of channel and floodplain facies, two major types of fluvial systems are distinguished in the non-confined, gently-sloping Triassic alluvial plains which are spread 


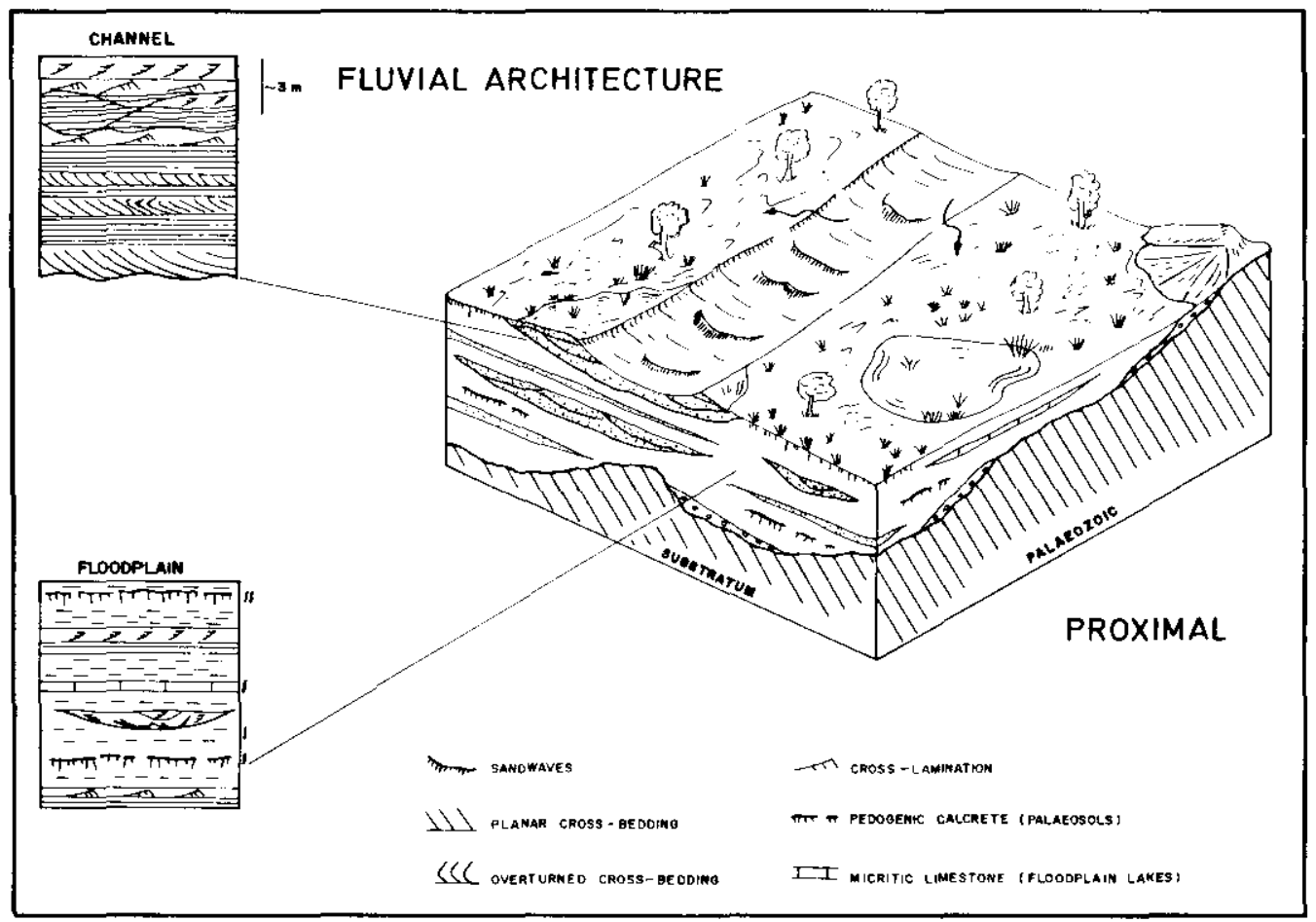

Fig. 8

Depositional model of the architecture of the proximal facies of sandy braided fluvial systems in the Triassic of Southern Spain. Both channel facies and floodplain facies are characterized by fining-upwards sequences. Typical features are the large amount of upper-flow plane beds and the rarity of levee and crevasse-splay facies (modified from Fernández and Dabrio 1983). Schematically, no scale.

along the southeastern edge of the Iberian Meseta. The river networks are related to proximal and distal areas of the basin.

\subsection{Proximal areas}

Proximal areas (cf. fig. 8) are characterized by a predominance of straight to low-sinuosity channels without or with only poorly-developed levees and infilied with sediments under rather high-energy conditions. A very typical feature is the internal fabric of the sandstone bodies (channel facies) which display fining-upwards sequences composed of two members. The lower memer records high-energy conditions within upper-flow paralle]-lamination (Plate II/11) and major erosional surfaces related to fully active channels during vigorous floods. The upper portion includes finer lower-flow plane-stratification and undulating horizontal-lamination with minor scour surfaces (Plate $I I / 10$ ) and other small-scale sedimentary structures (Plate II/7) such as climbing ripples that evidence low-energy conditions after partial abandonent of the channel due to avulsion. Similar sequences have been described by McKee, Crosby and Berryhill (1967) from the recent Bijou Creek (Colorado/USA). The most characteristic feature of these sediments which represent an environment dominated by flash flood conditions is the abundance of horizontal-lanination (facies Sh, Miall 1977).

The floodplain facies associated to the proximal-area channel facies are built up mostly by audstones, but layers of pedogenic nodular carbonate and parallel-lamina- 


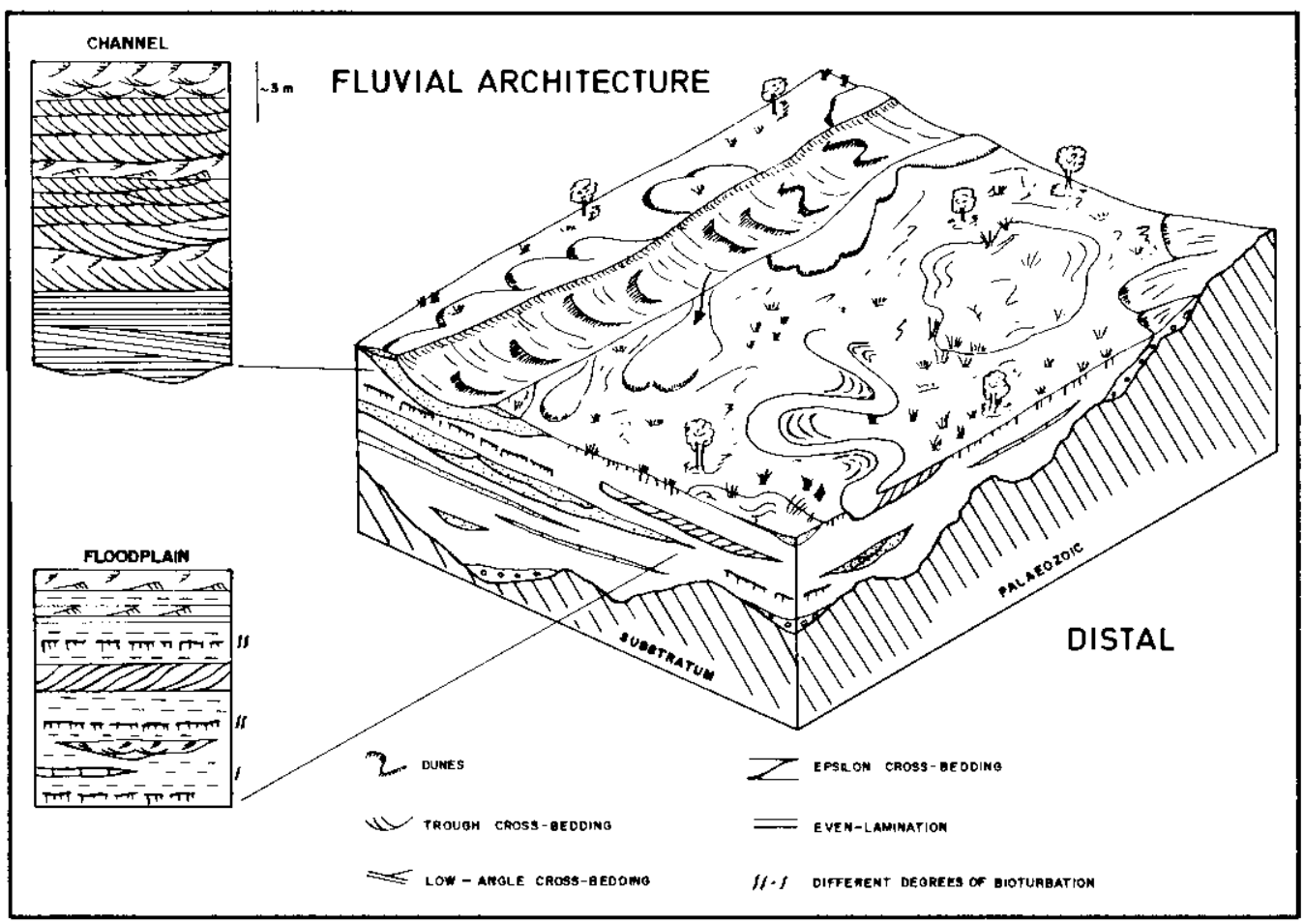

Fig. 9

Depositional model of the architecture of the distal facies of sandy braided fluvial systems in the Triassic of Southern Spain. Both channel facies and floodplain facies are characterized by fining-upwards sequences. Typical features are the lower level of energy indicated by the abundant cross-bedding in the channel facies, the presence of poorly-developed levees and crevasse-splays, and the existence of secondary small meandering watercourses between the large main streams (modified from Fernández and Dabrio 1983). Schematically, no scale.

ted algal mat carbonate (backswamp deposits) are also comon. Sandstone layers displaying fining-upwards sequences including horizontal-stratification and cross-lamination are attributed to sheet-flood overbanking of bed-load material. Ribbon sandstone bodies are thought to correspond to winor channels in the interstrean plain.

\subsection{Distal areas}

Distal areas (cf. fig. 9) are characterized by low-to moderate-sinuosity channels which are infilled with sand under lower energy conditions as compared to the proximal-area type stream networks. Levee belts are better developed. Sandstone bodies (channel facies) also display fining-upwards sequences that include parallel-lamination, cross-bedding with set thickness thinning upwards (cf. Plate II/6) and cross-lamination at the top (cf. Plate II/6). Erosional surfaces with low relief separate the fining-upwards sequences. The small number and large extent of such surfaces suggest that they are related not only to fluctuations of discharge but also to changes of the position of the depositional area. These sequences are in many cases very similar to those described by Smith $(1970,1971,1972)$ from the Platte river. The only difference refers to the bottom of sequences which is represented by longitudinal gravel bars (facies Gm) at the Platte river and by horizontal-laninated sheet sands (facies $S h$ ) in our example. 
In other cases, the lower parts of the sequences are formed by sandwaves (facies $\mathrm{Sp}$ ) being similar to the Brahmaputra sequences (Coleman 1969). Some features common with Devonian Battery Point Formation sequences (Cant and Walker 1976) or its modern equivalent, the South Saskatchewan river (Cant 1978, Cant and Walker 1978), can also be seen, but the bars (cross channel bars) found in the South Saskatchewan river do not appear in distal areas of the Buntsandstein-facies red bed fluvial systems (apart from this, the thicknesses of the red bed sequences are much greater than those of the South Saskatchewan sedimentary successions.

The floodplain facies are similar in both proximal and distal areas, but besides of the described features typically include tabular bodies of sandstone that (according to the internal structure) are identified as deposits of swall meandering streams in some cases and crevasse-splay channels and lobes in others.

In summary, during passage from proximal to distal areas, the channel facies record changes from mainiy plane beds and abundant diastems to predominantly megarippTes and a smaller number of erosional surfaces, whereas the floodplain facies show increasingly more backswamp, levee and crevasse-splay deposits along with sediments in small meandering channels (probably attributed to an interfluvial independent drainage system, cf. Allen and Williams 1979, cf. also Mader 1985a).

\section{Coastal evaporitic environments}

Evaporitic gypsu occurs in the upper part of the Triassic succession. The amount of gypsum varies from place to place. The thicker successions occur in those areas where the thickness of Triassic rocks reaches a maximum (cf. fig. 11).

A typical evaporitic succession includes four units (fig. 10). The lower one is made up of mdstone, cross-Taminated sandstone and some dolomicrites and represents a continuation of the floodplain facies. This unit passes gradually upwards into modstone with nodular gypsum that probably indicates deposition in a coastal plain with terrigenous influx.

The third unit consists of sandstone and gypsum. Gypsum occurs as noduies that become increasingly more abundant in upwards direction until they form a continuous layer with cottage-cheese texture. Several of these sequences which attain abt. 60-90 $\mathrm{cm}$ thickness can be present and are interpreted as supratidal sabkha deposits.

The topeost unit is gypsum of grey-green colour. Three textural sequences can be differentiated, that in ascending order consist of thinly-laninated gypsum, thick gypsum layer with chicken-wire fabric, and mudstone with nodules of gypsum. These sequences are interpreted as deposits of intertidal to supratidal zones including algal mats and nodules of anhydrite (later being totaliy replaced by gypsum).

The cudstones and evaporites originate in transgressive arid coastal sedimentary environments similar to that of the Persian Gulf (cf. Curtis, Evans, Kinsman and Shearman 1963; Kinsman 1966 and Purser 1973). The upper part of the intertidal zone and the supratidal sabkha are well represented.

The top of the Triassic succession is marked by a layer of breccia underlying the dolostones of assumed lower Jurassic age. This layer witnesses the general transgression of the circum-Tethys area that has been recognized on both sides of the Atlantic (Orti Cabo 1982). In that area, the depositional sequences of Triassic age are similar to those found along the southern edge of the Iberian Massif.

\section{Sedimentary model and palaeogeography}

The Triassic siliciclastic sediments along the southeastern border of the Iberian Massif are a good example of red beds deposited in an alluvial plain of low-sinuosity streans on a passive margin of the European plate. 


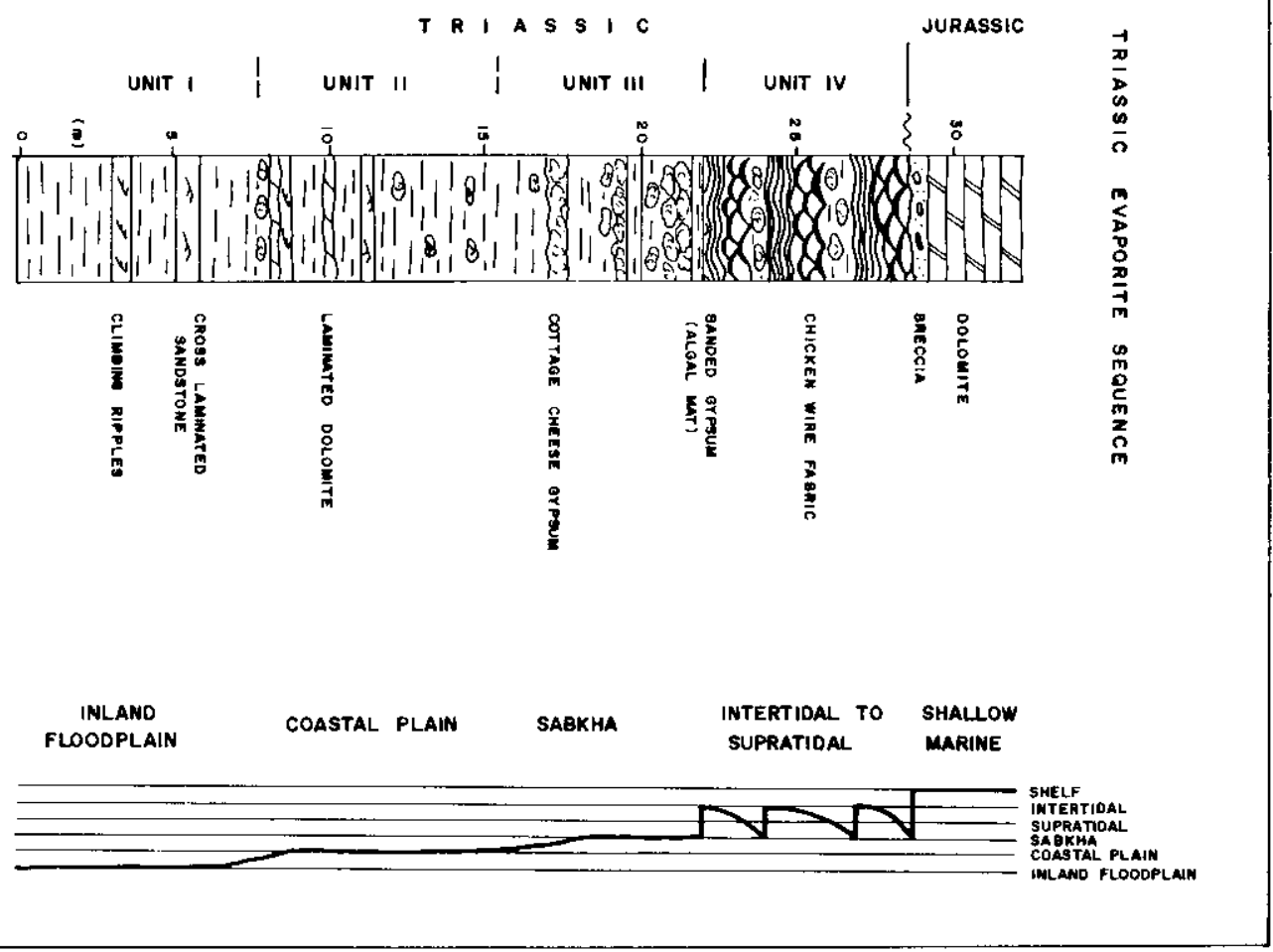

Fig. 10

Upper lutitic-evaporitic section at the top of the Triassic series. This section represents the transition from a fluvial environment to an arid-shoreline setting with evaporitic deposits. Within the passage belt, coastal plain, sabkha, intertidal and supratidal facies can be identified.

The pre-Triassic palaeogeography consists of a very irregular palaeorelief which is cut deeply into the Palaeozoic rocks of the Iberian Massif that in some places were not fully covered by red beds. The isopach map (fig. 11) shows several outstanding features:

1. Three elongated areas of maxima accusulation of sediments (Vilches and Genave with more than $400 \mathrm{~m}$ and Chiclana de Segura with more than $350 \mathrm{~m}$ ) thickness of the red bed sequence placed southwards of the central Palaeozoic relief and more or less parallel to it.

2. Areas of only thin sedimentary record (such as Santisteban del Puerto and Arroyo de 10 janco).

3. Areas of non-sedimentation corresponding to some place of the central Palaeozoic relief and areas located more to the north. These places were not covered by sediments and kept being erosional regions throughout the Triassic.

As a result, the maxim thicknesses are recorded southwards of the central Palaeozoic relief except of the surroundings of Linares (less than one hundred meters). The lower values of thickness were found northwards of the relief where less than $150 \mathrm{~m}$ were deposited and many pre-Triassic hills and inselbergs were not covered at all. 
ISOPACH Q EVAPORITES

DISTRIBUTION MAP

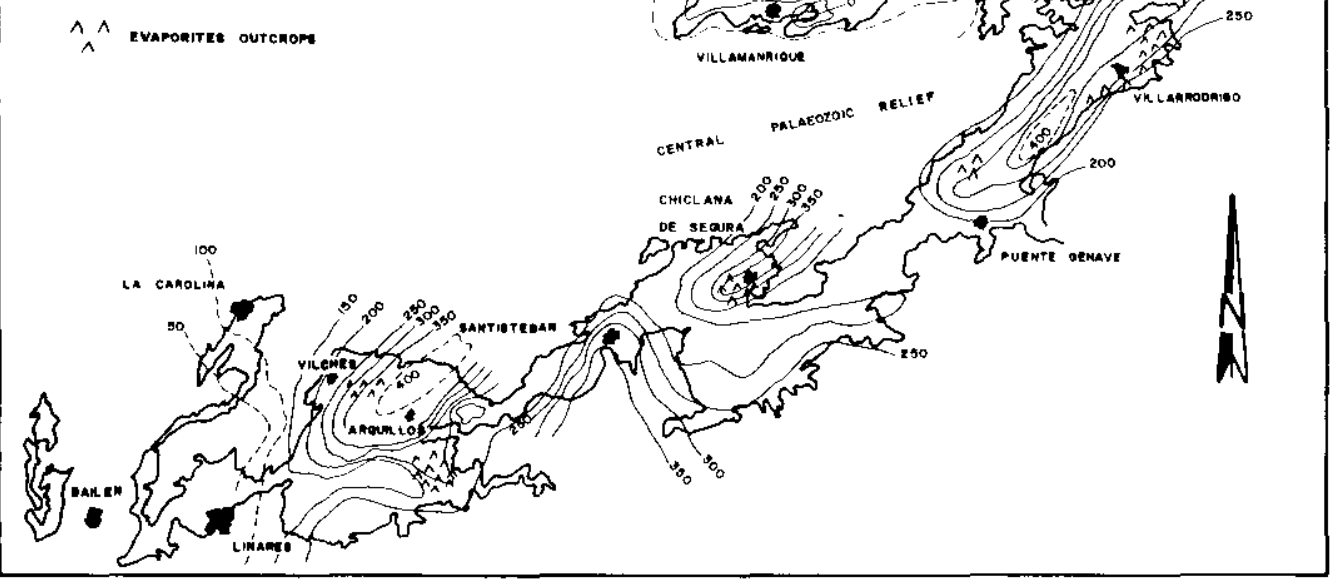

Fig. 11

Isopach map showing the evaporite outcrops and the pre-Triassic palaeogeography which determined the situation of the alluvial-fan deposits and the orientation of the main fluvial systems. These occur in the zones where the thickness of the accumulated materials is greatest (modified after Fernández 1977).

The distribution of sedimentary environments is largely controlled by the Hercymian palaeorelief, with alluvial fans existing close to the mountains, but being mostly developed along the northern edge of the Villanueva de la Fuente spur, and sandy braided systens (the bulk of the sedimentary record of this area) forming a broad bajada chain which is gently inclined towards the southeast as indicated by the palaeocurrent pattern (fig. 12). These rivers flowed radially away from the mountaineous region that acted as source area. According to Miall (1981, 1984), the river orientation would be transverse southwards of the Central Palaeozoic relief and longitudinal northwards of it.

The different magnitudes and effectivities of currents in channels and floodplain are nicely underlined by partially bimodal to even bipolar orientations of flows (for detailed evaluation of the significance of anomalous palaeocurrent directions of bimodal type in braided river systems cf. Mader and Teyssen 1985, Mader $1985 \mathrm{c}$ ).

Coastal evaporite deposits are limited to the upper parts of the stratigraphic sections of the southern edge of the Hercynian massif. Evaporites occur only in areas of maximum thickness of sediment (fig. 11). This striking fact suggests that they formed in areas of marked subsidence that were the first to be flooded during the transgression. No important evaporites were found around Villanueva de Infantes in the north of the Palaeozoic palaeorelief.

A definite climatic evidence cannot be drawn from the evaluation of the alluvial red beds (except of the calcrete palaeosols testifying to semi-arid settings). Palaeonagnetic determinations suggest that the sediments were formed between 20 and 


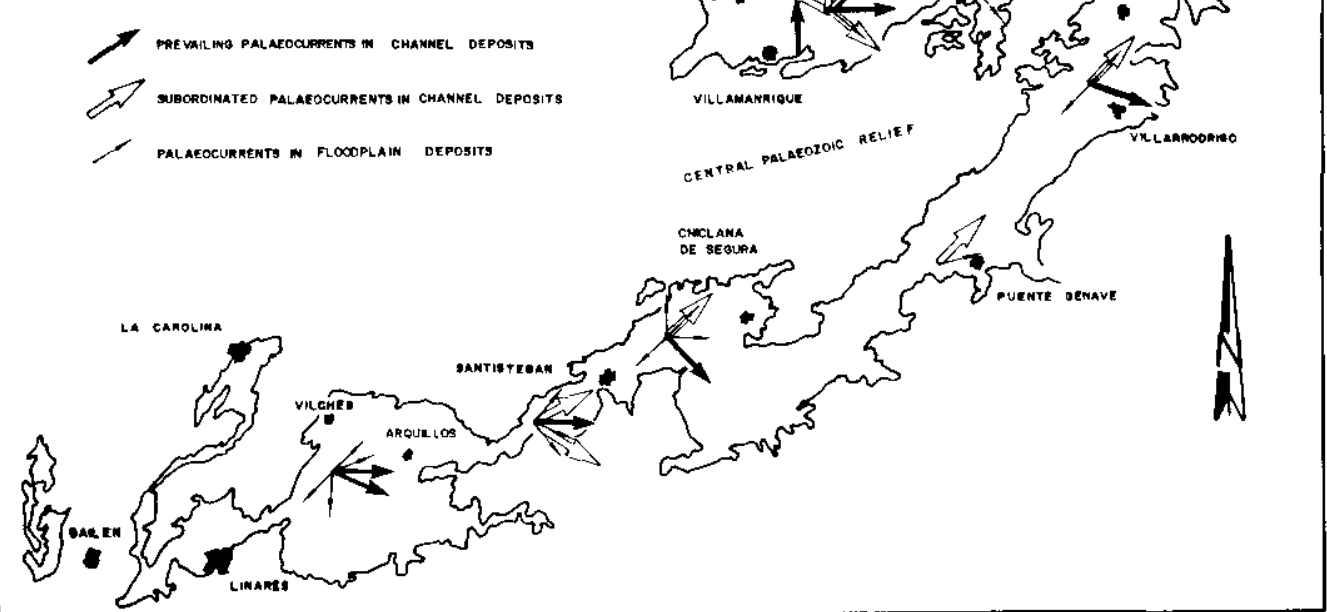

Fig. 12

Distribution of palaeocurrents in the fluvial Buntsandstein-facies red beds. Typical features are angular divergences and sometimes even bimodalities between currents of different magnitude and effectivity (the significance of bimodal to bipolar palaeocurrents is evaluated and interpreted in detail in Mader and Teyssen 1985). Modified from Fernández (1984).

$40^{\circ}$ north of the palaeoequator. There are, however, no present-day examples of low-latitude red beds. Many ancient red bed sequences are considered to be characterized by a diagenetic origin of their red colour, with intrastratal oxidation of iron silicates resulting in formation of ferric oxides and hematite that are responsible for reddening (for review of the problem cf. Mader 1983, 1985b).

\section{Economic interest of the Triassic rocks}

Copper mineralizations are the only economically interesting features in the Buntsandstein-facies red beds. Copper mineralizations occur both in the channel and the floodplain facies associations. The old mine of El Ahondillo in the neighbourhood of Navas de San Juan (cf. fig. 2) is the most interesting of all (having been abandoned during the twenties, the mine attracted new attention in recent years; Fernández and Perez Garcia 1983, Torres and Fernández 1983).

The mineralization is of strata-bound type with azurite, chrysocolla and malachite. From a sedimentological point of view, it is related to fine sediments (fine sands and mudstones with sedimentary structures indicating low-energy conditions), including plant debris, that are interpreted as deposits of secondary channels. The plant debris is usually limonitized or associated with hematitic iron oxides. The copper ores are mainly interstitial fillings which are present in intergranular spaces and fractures. The copper minerals often corrode the main components of the 
sandstone (quartz, feldspar and dolomite) due to replacement. The copper carbonates tend to concentrate preferentially close to the zories of plant debris (this phenomenon of the association of heavy metal concentrations to remnants of vegetation occurs also widespread in the Upper Buntsandstein of the Eifel and surrounding areas; cf. Mader and Kars 1985).

Mineralogical and textural studies reveal that the copper minerals originated during the late diagenesis under control of different fluids than those that induced the prominent early diagenetic transformations. Copper was leached as soluble sulphates from weathered prinary outcrops of sulphides located in the Hercynian massif after deposition (in addition, primary concentrations originated by sedimentation of copper ore grains along with the silicate sand, with the ore particles deriving from erosion of vein mineralizations in the basement). The drainage waters leaching the ores after deposition were of acid nature due to the oxidation of the sulphides, and they infiltrated into and migrated through the porous bodies of sandstone, interacting with the rock-constituting winerals. In course of this interaction, the fluids were progressively neutralized.

The copper ores were formed when proper physico-chemical barriers favoured the precipitation and crystallization. These barriers were the reduction of porosity due to the fine grain size of the sediments associated to the secondary channels, the interaction of solutions that carried the dissolved copper with the mineralogical constituents of the rocks, and the reducing effect of the plant debris. The origin of the meralization is at least in part of syngenetic type with already syndepositional concentration of the dispersed copper mineral grains in reaches of accumulation of plant debris. Subsequently, however, repeated mobilization and reprecipitation almost throughout the diagenetic evolution resulted in considerable overprinting of the original syngenetic nature thus in some parts of the sequence even minicking a wholly epigenetic nature (as also revealed by the diagenetic alterations of other light and heavy minerals; cf. Mader 1981, 1983, 1985b).

\section{Conclusions}

1. The Triassic palaeogeographical setting can be visualized as a large bay between the European and the African plates. Fluvio-lacustrine red beds of Buntsandstein facies surrounded the bay and graded laterally into the coastal and shallow marine carbonates of the Alpujarride facies (Alpine-like Triassic deposits). The southeastern edge of the Iberian Meseta was of irregular shape and the red beds and evaporites filled up the marked palaeorelief. The sediment sheets acted as rigid plates during the Alpine orogeny and were not deformed (tabular cover of the Meseta). According to palynological data, the age of the red beds ranges between the lowerwost Ladinian and the uppermost Norian.

2. Rare coarse sediments related to alluvial fans and conglomeratic braided rivers occur at the base of the sections in the vicinity of the Palaeozoic palaeoreliefs. Locally, sediments of the various zones of alluvial fans were found. The inner fan facies consists of debris-flow and mud-flow deposits. The mid fan sediments are built up of conglomerates, sandstones and mudstones arranged in fining-upwards sequences. The distal fan and pebbly braided river deposits are characterized by conglomerates, sandstones and mudstones associated to fluvial channels which also display fining-upwards sequences.

3. The bulk of the Triassic successions is the result of deposition by 10n-sinuosity sandy rivers. The channel facies is built up of fining-upwards megasequences related to shifting of alluvial subenviroments which are in turn composed of fining-upwards microsequences related to fluctuations of flow. The proximal floodplain facies (including levees) usually consists of interbedded mudstones and sandstones with thickening-upwards organization. The internal structure of the sandstone layers records the decrease of flow energy both towards the top with progressive infilling of the channel and to the distal parts of the floodplain with decelerating capacity of the water surges. Layers of pedogenic carbonates and horizons with much iron oxi- 
des are also present. Far away from the channels, thick accumulations of mudstone were laid down forming the distal floodplain facies. The distal overbank mudstones contain intercalations of laminated micrites and fine sand and silt which, however, lack any significant sequential arrangement.

4. Lateral wandering of all those closely related environments resulted in various types of fluvial sequences. The active mechanism was the progressive infilling of the channel that caused an increased importance of the floodplain processes with declining water depth and ameliorated overtopping of the levees by flood surges. As the rate of sedieentation in the channel areas was higher than in the topstratua flat, the channel progressively aggraded until it eventually became unstable and moved away by avulsion to a new course. The highly variable superposition of facies that resulted from these lateral changes of position account for the many different sequences found in the Triassic Buntsandstein-facies red beds.

5. Considering the whole fluvial facies, some differences exist in the fluvial architecture between proximal and distal areas. In proximal areas, the channel facies is characterized by upper-flow regime plane beds, whereas in the distal zones, cross-bedding originating by migration of megaripples predominates. The number of scour surfaces decreases towards the distal areas, because the incidence of fluctuations of flow is smaller in that direction. Floodplain deposits of the distal areas of the fluvial systems include common backswamp and crevasse-splay intercalations as well as some minor meandering channels between the main braided streams, testifying to a higher stability of the fluvial system in the distal areas.

6. The fluvial facies change gradually into the sabkha sediments and intertidal deposits of the evaporitic-lutitic unit. At the top of all the sections, the shallow-marine Early Jurassic limestone records the extensive transgression that took place in the circum-Tethys regions at the end of the Upper Triassic.

7. The existence of strata-bound copper ores, associated to deposits of inactive secondary channels, reinforces the need of sedimentological studies for prospection of these minerals.

\section{Acknowledgements}

Thanks are due to Dr. P.F. Friend (Cambridge/England) for commenting on severa? problems in relation with this paper, to Dr. D. Mader (Hannover/F.R. Germany) for improving our manuscript by considerable editorial polishing and numerous suggestions, and to Prof. Dr. J. Rodriguez (Canada) for supply of the photos.

\section{References}

Allen, J.R.L. (1964): Studies in fluviatile sedimentation: six cyclothems from the Lower Old Red Sandstone, Anglo-Welsh Basin. - Sedimentology, 3: 163-198; Amsterdan.

Allen, J.R.L. (1965): A review of the origin and characteristics of recent alluvial sediments.- Sedimentology, 5: 89-191; Amsterdam.

Allen, J.R.L. (1974): Studies in fluviatile sedimentation: implications of pedogenic carbonate units, Lower old Red Sandstone, Anglo-welsh outcrop.- Geol. J., 9: 181-208; Liverpool.

Allen, J.R.L. and Williams, B.P.J. (1979): Interfluvial drainage on Siluro-Devonian alluvial plains in wales and the welsh Borders.- J. Geol. Soc. Lond., 136: 361-366; London.

Bessems, R.E. (1981): Aspects of Middle and Late Triassic Palynology. 1. Palynostratigraphical data from the Chiclana de Segura Formation of the Linares-Alcaraz region (Southeastern Spain) and correlation with palynological assemblages from the Iberian Peninsula.- Rev. Palaeobot. Palynol., 32: 257-273; Amsterdam.

Bourgois, J. (1980): De l'origine ultra-Bétique des Málaguides (Zone internes 
Bétiques, Espagne).- Geologica Romana, 19: 151-170.

Bull, W.B. (1972): Recognition of alluvial-fan deposits in the stratigraphic record.- In: Rigby, K.J. and Hamblin, W.K. (Editors), Recognition of ancient sedimentary environments. Soc. Econ. Paleont. Miner., Spec. Publ., 16: 68-83; Tulsa/Oklahoma.

Cant, D.J. (1978): Development of a facies model for sandy braided river sedimentation: comparison of the South Saskatchewan river and the Battery Point Formation.- In: Miall, A.D. (Editor), Fluvial sedimentology. Canad. Soc. Petrol. Geol. Mem. , 5: 627-639; Calgary/Alberta.

Cant, D.J. and Walker, R.G. (1976): Development of a braided-fluvial facies model for the Devonian Battery Point Sandstone, Quebec.- Canad. J. Earth. Sci., 13: 102-119; Dttawa/Ontario.

Cant, D.J. and Walker, R.G. (1978): Fluvial processes and facies sequences in the sandy braided South Saskatchewan River, Canada.- Sedimentology, 25: 625-648; Oxford.

Collinson, J.D. (1970): Bedforms of the Tana River, Norway.- Geogr. Annal., 52A; $31-56$.

Collinson, J.D. (1978): Alluvial sediments.- In: Reading, H.G. (Editor), Sedimentary environments and facies, 15-61; Oxford (Blackwell).

Coleman, J.M. (1969): Brahmaputra River: channel processes and sedimentation.Sedim. Geol., 3: 129-239; Amsterdam.

Curtis, R., Evans, G., Kinsman, D.J.J. and Shearman, D.J. (1963): Association of dolomite and anhydrite in the recent sediments of the Persian Gulf.- Nature, 197: 679-680; London.

Dabrio, C.J. and Fernández, J. (1980): Secuencias originadas por la migración de rios arenosos de baja sinuosidad.- Estud. Geol., 36: 371-381; Madrid.

Dewey, J.F. et al. (1973): Plate tectonics and the evolution of the Alpine System.Geol. Soc. Amer. Bull., 84: 3137-3180; Boulder/Colorado.

Fernández, J. (1977): La sedimentación triásica en el borde sureste de la Meseta.- Tesis Doctoral (Ph. D. Thesis) Univ. Granada, 161: 169 pp.; Granada.

Fernández, J. (1984): Capas rojas triásicas del borde sureste de la Meseta. Sintesis estratigráfica y sedimentológica.- Mediterranea, Serie de Estud. Geol., 3: 89-105.

Fernández, J. and Dabrio, C.J. (1983): Secuencias proximales y distales en rios de baja sinuosidad.- $X$. Congr. Nacional de Sediment. pp. 1.17-1.20.

Fernàndez, J. and Pérez Garcia, L.C. (1983): Las mineralizaciones de cobre en rios arenosos de baja sinuosidad (Triasico al $\mathrm{N}$ de la provincia de Jaén, Espana).- Bol. Geol. Minero., XCIV-II: 121-128.

Friend, P.F. (1983): Towards the field classification of an alluvial architecture or sequence.- In: Collinson, J.D. and Lewin, J. (Edicors), Modern and ancient fluvial systems. Spec. Publs int. Ass. Sediment., 6: 345-354; 0xford (Blackwell).

Friend, P.F. and Moody-Stuart, M. (1970): Carbonate deposition on the river floodplains of the Wood Bay Formation (Devonian) of Spitsbergen.- Geol. Mag., 107: 181-195; London.

Friend, P.F., Slater, M.J. and Williams, R.C. (1979): Vertical and lateral building of river saudstone bodies, Ebro Basin, Spain.- J. Geol. Soc. Lond., 136: 39-46; London.

Kinsman, D.J.J. (1966): Gypsum and anhydrite of recent age, Trucial Coast, Persian Gulf.- In: Pan, J.L. (Editor), Second Symposium on salt. Vol. I, pp. 302-326. Northern Ohio Geol. Soc.; Cleveland/Ohio.

Leeder, M.R. (1974): Lower Border Group (Tournaisian) fluviodeltaic sedimentation and palaeogeography of the Northumberland Basin.- Proc. Yorks. Geol. Soc., 40: 129-180; Hu11.

Leeder, M.R. (1975): Pedogenic carbonate and flood sediment accretion rates: a quantitative model for alluvial, arid-zone lithofacies.- Geol. Mag., 112: 257-270; London.

López Garrido, A.C. (1971): Geologia de la Zona Prebética al NE de la provincia de Jaén.- Tesis Doctaral (Ph. D. Thesis) Univ. Granada., 296 pp.; Granada.

Mader, D. (1981): Diagenesis of the Buntsandstein (Lower Triassic) in Western Eifel (Germany). - N. Jb. Miner. Abh., 142: 1 - 26; Stuttgart.

Mader, D. (1983): Primäre und sekundäre Eisenoxide im Buntsandstein der Westeifel 
- ein Beitrag zu Lenese der Rotfärbung in der germanischen Trias. Teil I, Verteilung der Eisenoxide und Merkmale der Rotfärbung. Teil II. Deutung der Pigmentgenese. - Z. geol. Wiss., 11: 603 - 637, 729-767; Berlin.

Mader, D. (1985a): Polyzyklische Evolution der fluviatilen Sedimentation im Mittleren Buntsandstein von Oberfranken (Ostbayern). - In: Mader, D. (Editor), Beiträge zur Genese des germanischen Buntsandsteins. 481 - 540; Hannover (Sedimo).

Mader, D. (1985b): Diagenetic evolution of opaque and transparent heavy minerals reflecting colour genesis in continerital fluvial Buntsandstein red beds of the Eifel (F.R. Germany). - In: Mader, D. (Editor), Aspects of fluvial sedimentation in the Lower Triassic Buntsandstein of Europe. Lecture Notes in Earth Sciences, 4: 531 - 560; Berlin/Heidelberg/New York/Tokyo (Springer).

Mader, D. (1985c): Bimodal palaeocurrents in braided-type inland fluvial environments in the Buntsandstein of Middle Europe and other continental formations. In: Mader, D. (Editor), Aspects of fluvial sedimentation in the Lower Triassic Buntsandstein of Europe. Lecture Notes in Earth Sciences, 4: 436 - 446; Berlin/ Heidelberg/New York/Tokyo (Springer).

Mader, D. and Kars, H. (1985): Provenance determination of Buntsandstein artefacts from the Early-Medieval Dorestad trading site (The Netherlands): an example of the significance of geological-mineralogical analysis in archaeology. - In: Mader, D. (Editor), Aspects of fluvial sedimentation in the Lower Triassic Buntsandstein of Europe. Lecture Notes in Earth Sciences, 4: 591 - 624; Berlin/ Heidelberg/New York/Tokyo (Springer).

Mader, D. and Teyssen, T. (1985): Palaeoenvironmental interpretation of fluvial red beds by statistical analysis of palaeocurrent data: examples from the Buntsandstein (Lower Triassic) of the Eifel and Bavaria in the German Basin (Middle Europe). - Sedim. Geol., 41: 1 - 74; Amsterdam.

McGowen, J.H. and Groat, C.G. (1971): Van Horn Sandstone, West Texas: an alluvial fan model for mineral exploration.- Bur. Econ. Geol. Rept. Invest., 72: 57 pp.; Austin/Texas.

McKee, E.D., Crosby, E.J. and Berryhill, H.L.Jr. (1967): Flood deposits, Bijou Creek, Colorado, June 1965.- J. Sedim. Petrol., 37: 829-851; Tulsa/Oklahoma.

Miall, A.D. (1977): A review of the braided river depositional environment.- Earth Sci. Rev., 13: 1-62; Amsterdam.

Miall, A.D. (1981): Alluvial sedimentary basins: tectonic setting and basin architecture.- In: Miall, A.D. (Editor), Sedimentation and tectonics in alluvial basins, with examples from North America. Geol. Assoc. Can., Spec. Pap., 24; Ottawa/Ontario.

Miall, A.D. (1984): Principles of sedimentary basin analysis.- 480 pp.; Berlin/Heidelberg/New York/Tokyo (Springer).

Moody-Stuart, M. (1966): High-and Iow-sinuosity stream deposits, with examples from the Devonian of Spitsbergen.- J. Sedim. Petrol., 36: 1102-1117; Tulska/Oklahoma.

Orti Cabo, F. (1982): Sur les conditions de dépôt, la diagenèse et la structure des evaporites triasiques dans l'Est de I'Espagne GRECO 52 . Le Trias évaporitique de France et Pays limitrophes.- Nancy (Sciences de la Terre).

Purser, B.H. (1973): The Persian Gulf: Holocene carbonate sedimentation and diagenesis in a shallow epicontinental sea.- $471 \mathrm{pp}$.; Berlin/Heidelberg (Springer).

Smith, N.D. (1970): The braided stream depositional environment: comparison of the Platte River with some Silurian clastic rocks, north-central Appalachians.- Geol. Soc. Amer. Bull., 81: 2993-3014; Boulder/Colorado.

Smith, N.D. (1971): Transverse bars and braiding in the lower Platte River, Nebraska.- Geol. Soc. Amer. Bull., 82: 3407-3420; Boulder/Colorado.

Smith, N.D. (1972): Some sedimentological aspects of planar cross-stratification in a sandy braided river.- J. Sedim. Petrol., 42: 624-634; Tulsa/Oklahoma.

Smith, N.D. (1974): Sedimentation and bar formation in the Upper Kicking Horse River, a braided outwash stream.- J. Geol., 82: 205-223; Chicago.

Tamain, G. (1972): Recherches géologiques et minières en Sierra Morena Orientale (Espagne).- Thèse Univ. Paris-Sud (Centre d'Orsay), $369 \mathrm{pp}$.

Torres Ruiz, J. and Fernández, J. (1983): Génesis de las mineralizaciones de cobre en las capas rojas triásicas del sector de Navas de San Juan (Provincia de Jaén).- Bol. Geol. Minero., XCIV-III: 244-258. 